\title{
تصور مقترح لبرنامج يعتمد على الأكاء الاصطناعي لتحديد الاحتياجات التدريبية للمعلمين وتنمية قار اتهم المهنية
}

\section{نوال بنت صويلح حمدان الجهني}

\section{ملخص الدراسة}

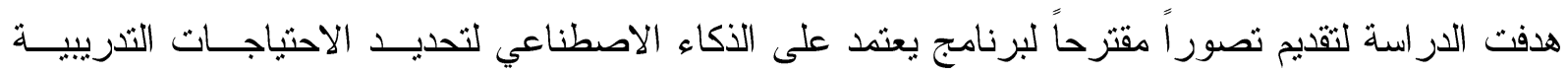

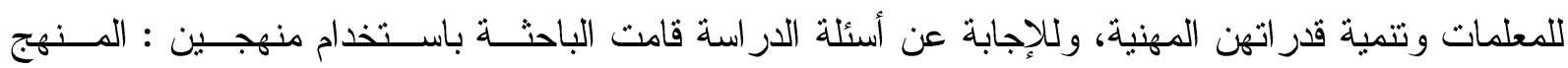

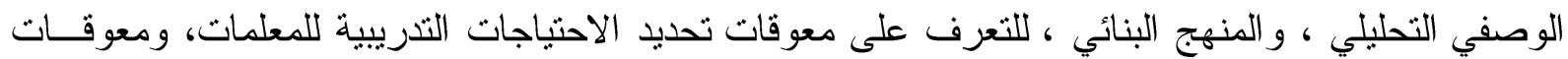

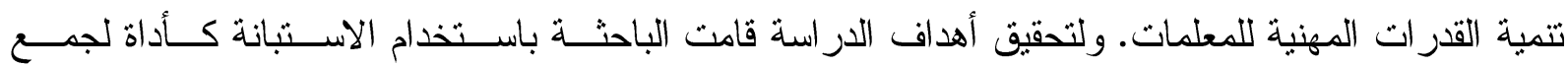

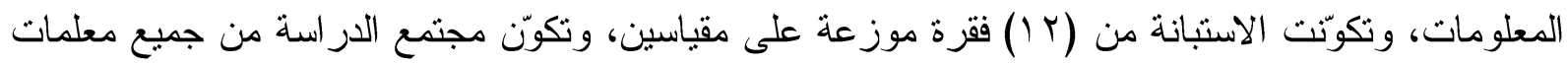

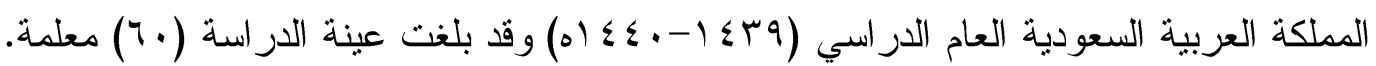
وقد توصلت الدراسة إلى عدة نتائج، من أهمها:

ا. قدمت الدارسة تصورًا مقترحًا لبرنامج يعتد على الذكاء الاصطناعي لتحديد الاحتباجـات التنريبيــة اللمعلمات وتتمية قدر اتهن المهنية. r. أظهرت الدراسة أن درجة معوقات تحديد الاحتياجات التنريبية للمعلمات من وجهة نظرهن، جـاءت بدرجة متوسطة، بنسبة تأييد . 10.0\%

r. أظهرت الدراسة أن معوقات تتمية القدرات المهنية للمعلمات من وجهة نظرهن، جاءت بدرجة كبيــرة

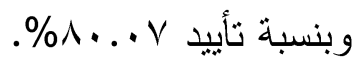
وبناءً على نتائج الدراسة، كان من أهم توصياتها:

ا. ب. ثبني التصور المقترح من قبل وزارة التعليم في المملكة العربية السعودية.

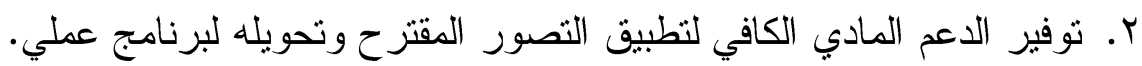
r. ب. قياس أثز البرنامج على أداء المعلمات ونطويره بناء على هذه النتائج. 


\section{Abstract}

The study aimed to provide a suggested concept for a program rely artificial intelligence to determine the training needs of teachers and develop their professional abilities, to answer the study questions, the researcher used two methods, descriptive analytical approach to identify the obstacles to identify the training needs of teachers, and obstacles to the development of professional capacity of teachers, and to achieve the objectives of the study the researcher used the questionnaire as a tool to collect information, the questionnaire consisted of $(I)$ items distributed on two scales. The study population consisted of all the teachers of Saudi Arabia in the academic year ( $1 \leqslant r q-1 \leqslant \varepsilon \cdot)$.

The study has reached several results, the most important of which are:

1. The study presented a suggested concept for a program rely artificial intelligence to identify the training needs of teachers and develop their professional abilities.

$r$. The study showed that the degree of impediments to determining the training needs of teachers from their point of view even medium with a support rate of $70.0 \%$

$r$. The study showed that the obstacles to the professional development of teachers, in their view, came to a large extent with the support of $\wedge . . \vee \vee \%$.

Based on the results of the study, the most important recommendations were:

1. Adopt the concept proposed by the Ministry of Education in Saudi Arabia.

r. Provide adequate financial support for the implementation of the proposed perception and transform it into a practical program.

$r$. Measure the impact of the program on teachers performance and development based on these results. 
يعد المعلم حجر الزاوية في العملية التعليمية، فيلقى على عانقه نجاح العملية التعليمية، لذا فهو في أمسّ الحاجة

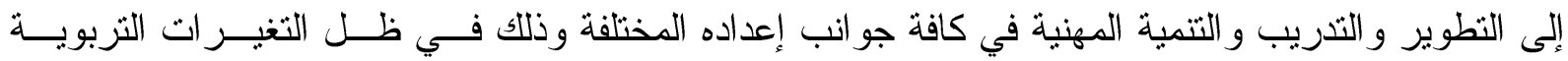

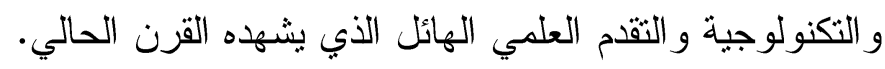

تعدّ التّمية المهنية للمعلم من أساسيات تحسين التعليم وتطويره، وذلك لما لها من أهمية بالغة في تطوير الأداء

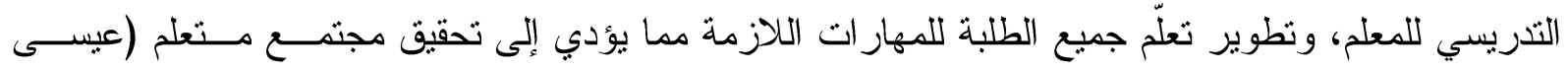

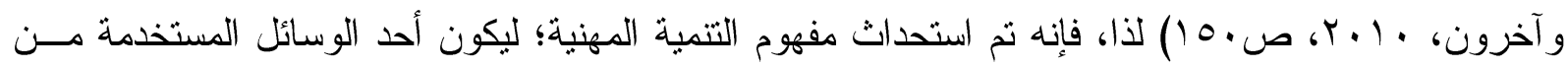

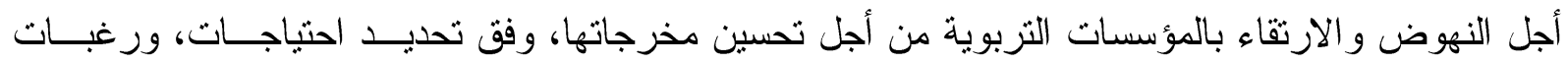

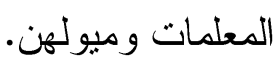

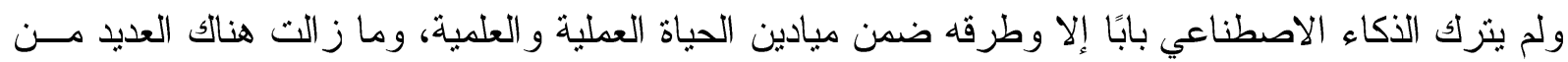

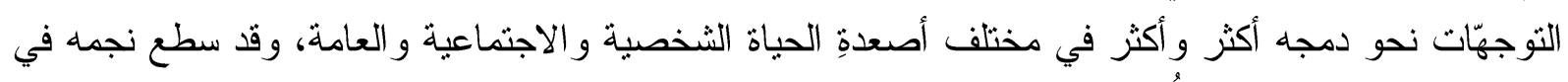

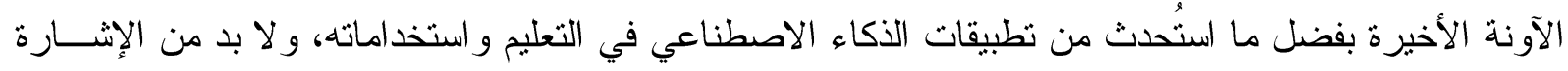

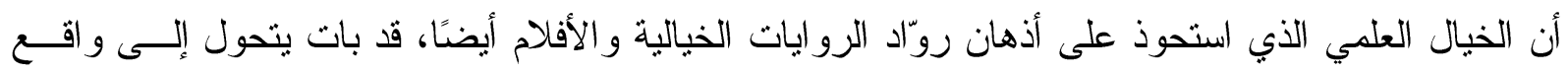
ملموس بشكل تدريجي.

يعدّ الذكاء الاصطناعي أحد علوم الحاسب الآلي الحديثة التي تبحث عن أساليب منطورة لبرمجته للقبام بأعمال

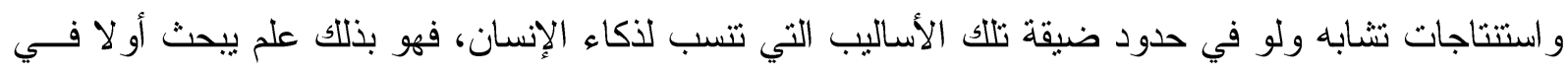

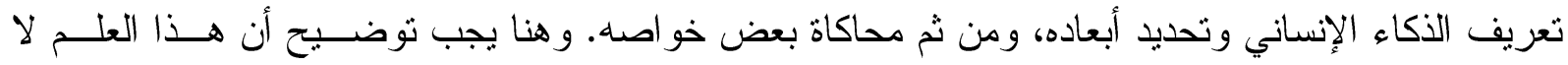

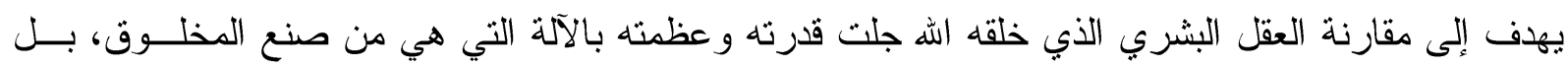

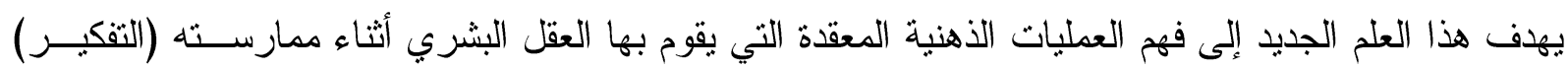

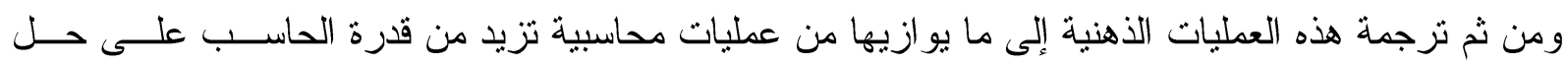

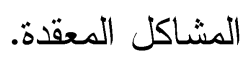

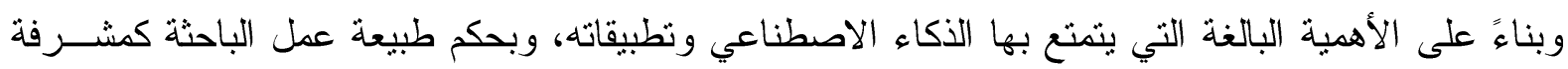

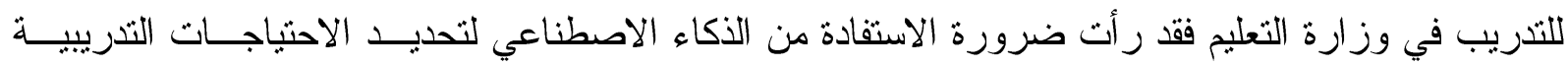
وتتمية قدر ات المعلمات المهنية.

\section{مشكلة الدراسة:}

إنَّ قضية إعداد المعلم وتتميته مهنيًا لم تعد قضية ثانوية، بل قضية مصيرية تمليها تطور ات الحياة، لا سيما في

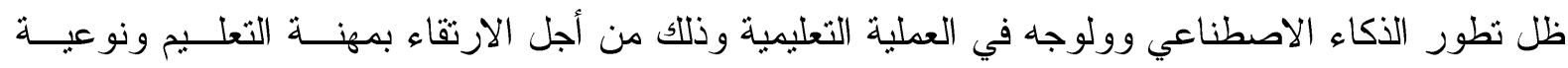

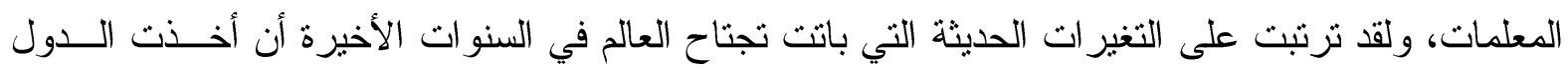

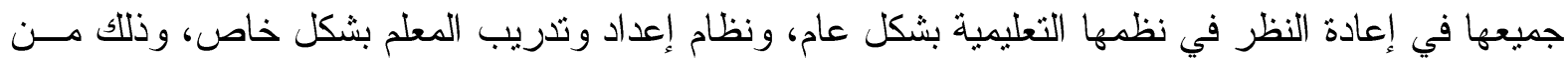

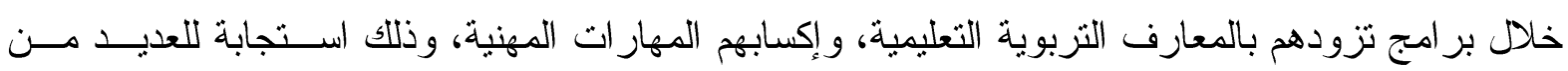

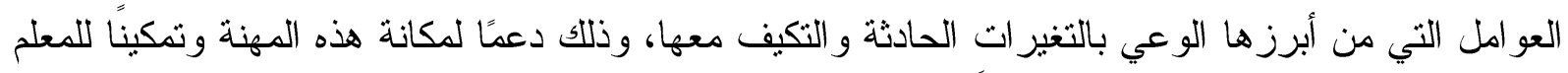

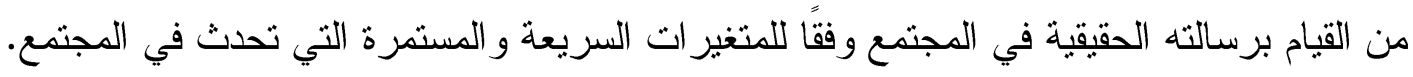




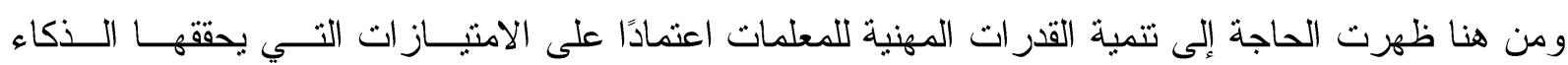
الصناعي ومن هنا فقد تمثلت مشكلة الدر اسة في الإجابة عن التشاؤلات الثالية:

1. ـا درجة معوقات تحديد الاحتباجات التنريبية للمعلمات من وجهة نظرهن ؟ r. ما درجة معوقات تتمية القدر ات المهنية للمعلمات من وجهة نظرهن؟

ما التصور المقترح لبرنامج يعتمد على الذكاء الاصطناعي لتحديد الاحتياجات التنرييية للمعلمات وتتمية

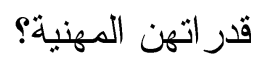

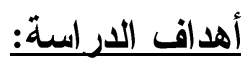

ا ب . بيان درجة معوقات تحديد الاحتياجات التنريبية للمعلمات من وجهة نظرهن.

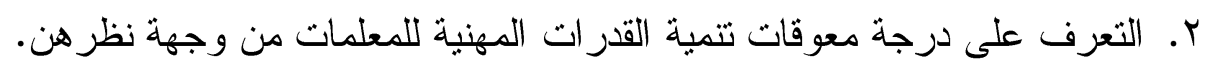

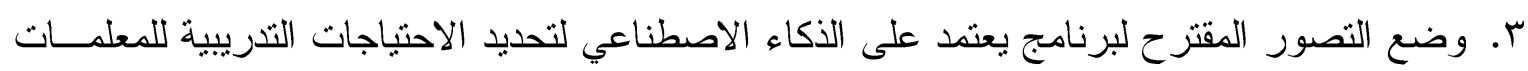
وتتمية قدر اتهن المهنية.

أهمبة الدراسة

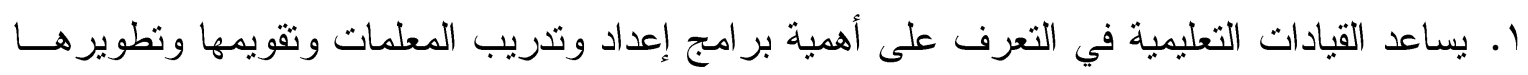

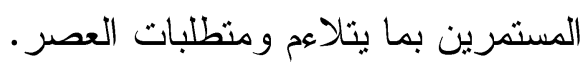

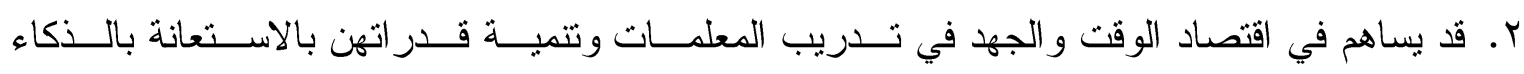
الاصطناعي.

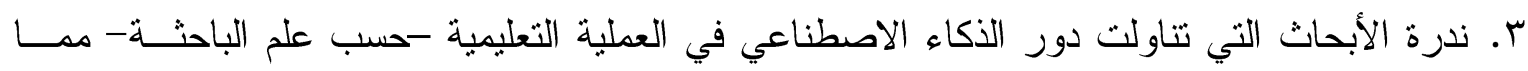

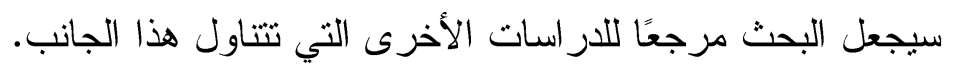

ع. قد تساعد الدر اسة الحالية القائمين على التعليم في إعادة النظر نحو برامج التنمية المهنية و التطويريـــة التي تقدم للمعلمات.

ه. إثراء المكتبة العربية بدراسة على قدر كبير من الأهمية تتعلق بتحديد الاحتياجات التنديبــة و التتميــة المهنية للمعلمات باستخدام الذكاء الاصطناعي. لصني.

حدود اللارسة:

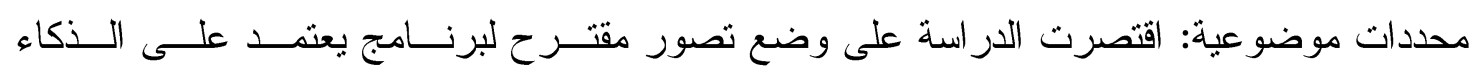

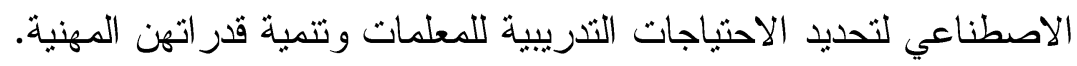

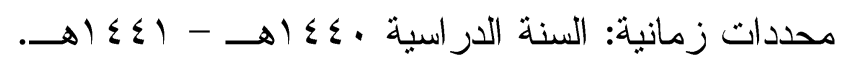
محدات مدات مكانية: المملكة العربية السعودية. محددات بشرية: معلمات التعليم العام بوزارة التعليم ـ محند 
الذكاء الصناعي: يمكن تعريف الذكاء الصناعي بأنه "تصرف الجهاز الذي لــو عملــهـ الإنسان فسيطلق عليــهـ

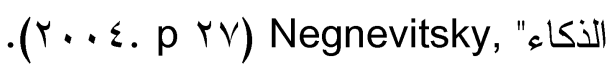

وتعرفه الباحثة إجر ائيًا: "هو دراسة كيفية توجيه الحاسب لتحديد الاحتياجات التدريبية للمعلمات و العمل على لـى

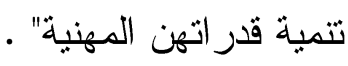

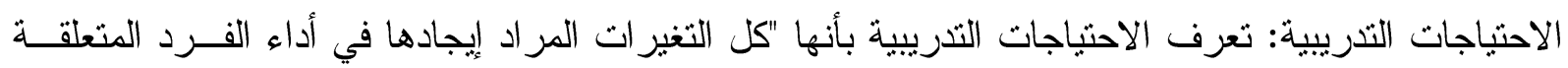

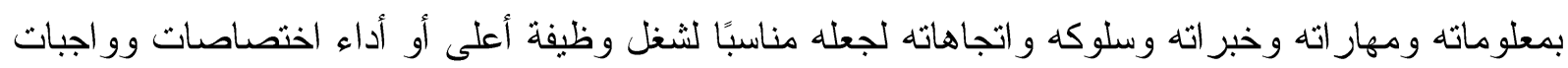

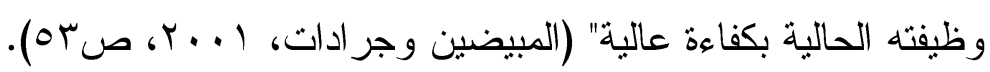

وتعرفها الباحثة إجرائًا بأنها: "جميع الكفايات التربوية التي تحتاجها المعلمة في المملكة العربية السعودية التي لتئي

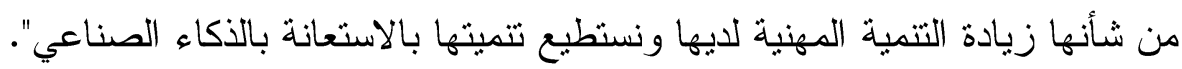

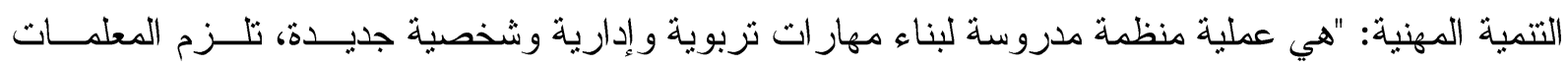

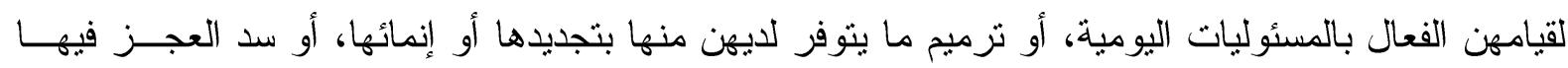

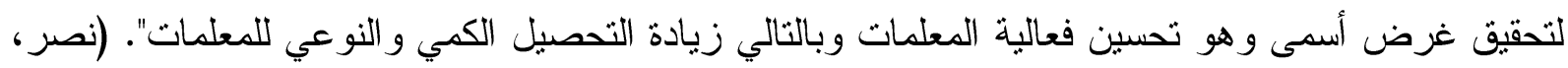

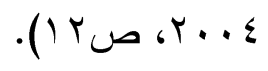

المحتوى النظري للار اسة: المحور الأول: الأكاء الاصطناعي: أويًا: مفهوم الذكاء الاصطناعي:

يمكن تعريف الذكاء الاصطناعي بأنه: "علم يهتم بصناعة آلات تقوم بتصرفات بعتبر ها الإنسان تصرفات ذكية"

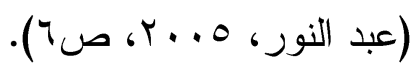

يعرف الذكاء الاصطناعي بأنه: "الذكاء الذي تبديه الآلات و البرامج بما يحاكي القدرات الذهنية البشرية و أنماط

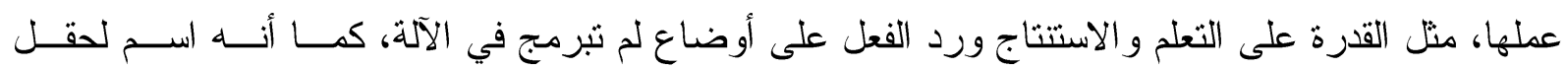

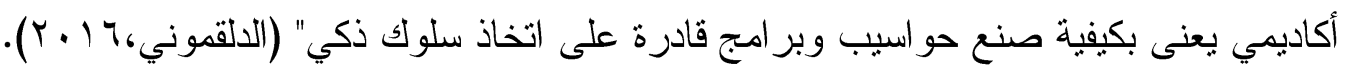

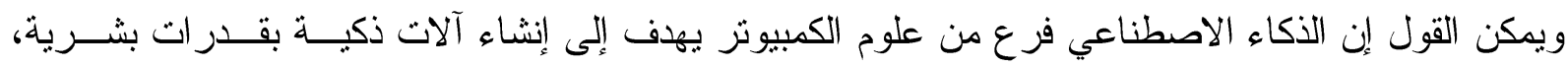

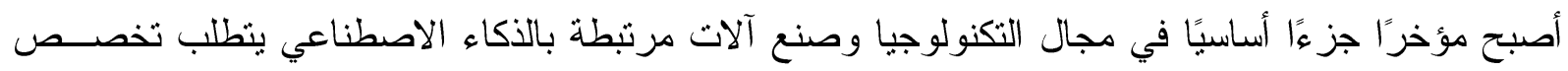

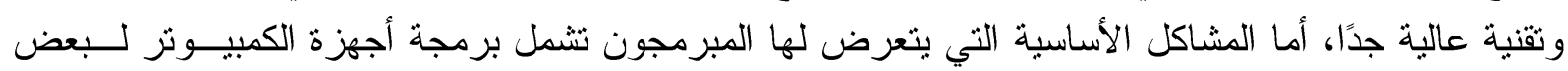

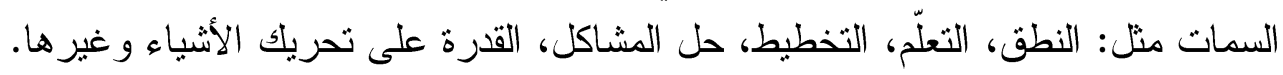

ثنانبًا: أهمبة الذكاء الصناعي:

إن أهمية الذكاء الاصطناعي أكبر من أن تحصى في نقاط سريعة ولكن يمكن الإشارة إلى بعض جو انبها ومنها

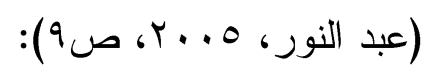




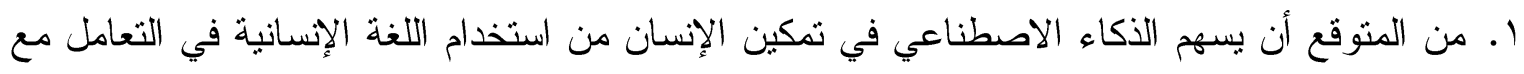

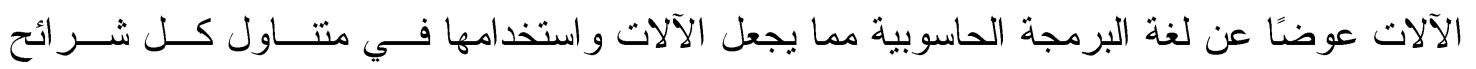

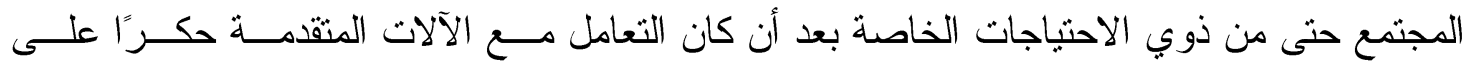

$$
\text { المختصين وذوي الخبر ات. }
$$

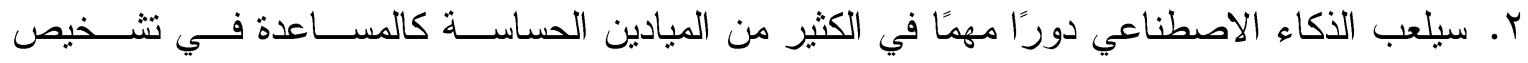

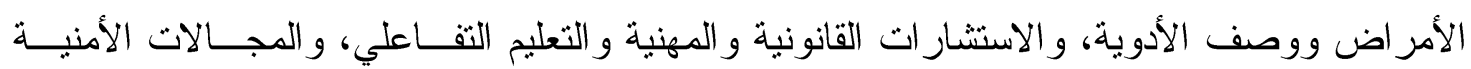

$$
\text { و العسكرية. }
$$

r. ستسهم الأنظمة الذكية في المجالات التي يصنع فيها القزار فهذه الأنظمة تتمتع بالاســتقلالية و الدقــة

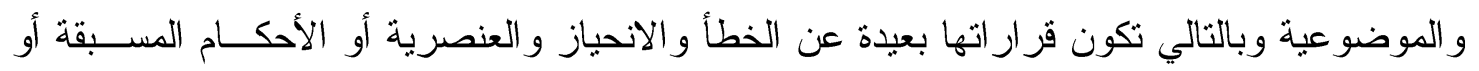

$$
\text { حتى التخخلات الخارجية أو الثخصية. }
$$

ع. ستخفف الآلات الأكية عن الإنسان الكثير من المخاطر و الضغوطات النفسية وتجعله بركز على أثياء أكثر أهمية و أكثر إنسانية ويكون ذلك بتوظيف هذه الآلات للقيام بالأعمال الشاقة و الخطرة و استكشاف

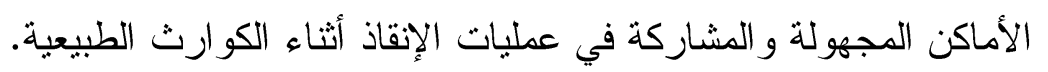

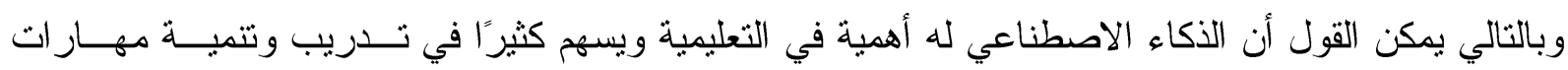
المعلمات، وتلخص الباحثة هذه الأهمية على النحو التالي: لاهئ

ا. ـ من المتوقع أن يسهم الذكاء الصناعي في تمكين المعلم من التدرب ذاتيًا. r. ستوفر الآلات الذكية على المعلم الوقت و الجهد في شتى مجالات عمله. r. ستساعد المعلم على إدارة أعماله واحتباجاته التدريبية بشكل أكثر تتظيمًا و أكثر مساعدة.

\section{ثالثًا: أهمبة الأكاء الصناعي في التعليم:}

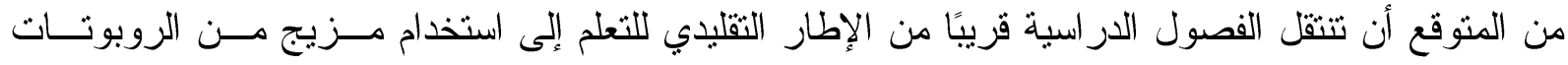

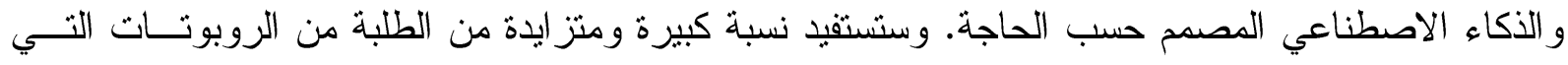

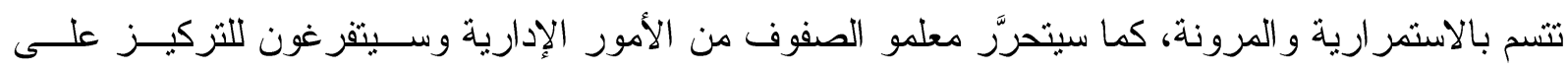

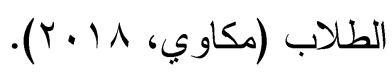

فالمعلمون كثيرًا ما يعانون من كثرة الأعمال المكتبية، مثل تصحيح الامتحانات وتقييم الو اجبات. ولكن يمكـن الأن

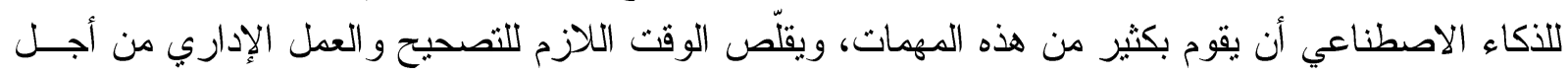
تكريس مزيد من الوقت للطلاب.

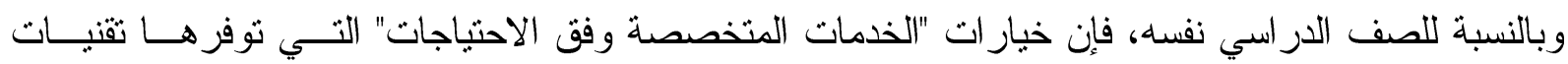

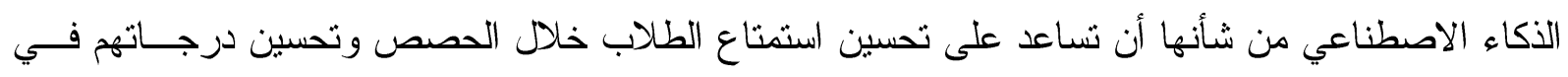

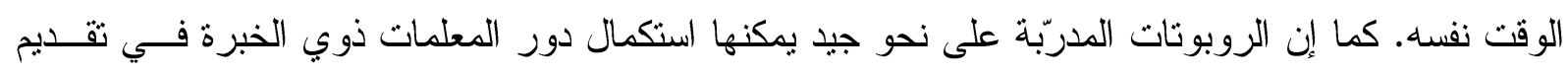

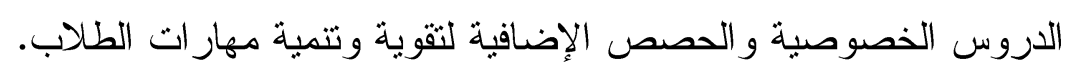

وتسنطيع هذه التقنية أن تحل مشكلات قلة المعلمات أو شح توفر المعلمات الأكفاء في بعض المجالات. فهـي

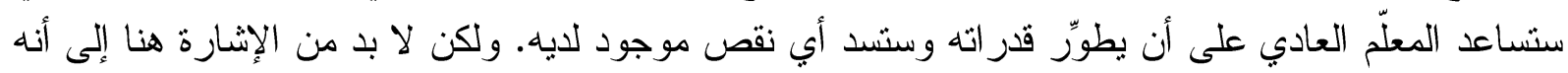




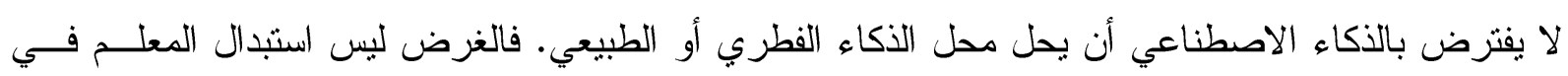

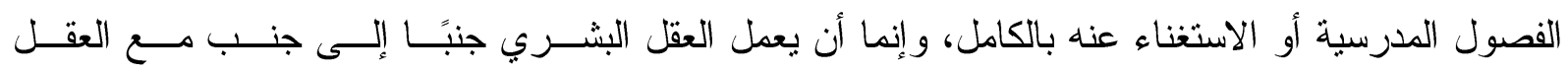
الاصطناعي في توليفة محسوبة متقنة.

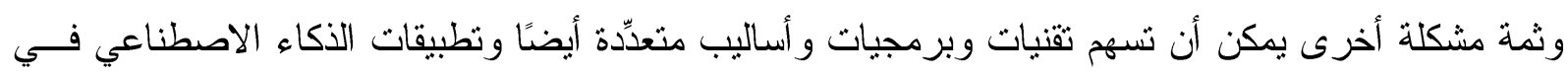

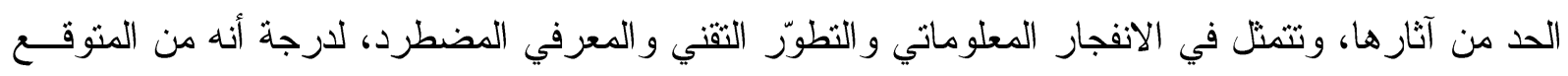

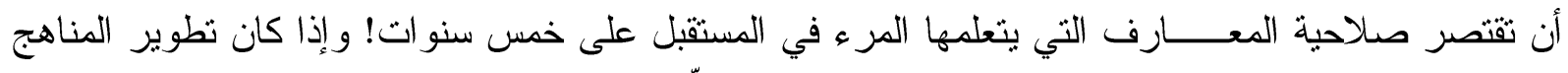

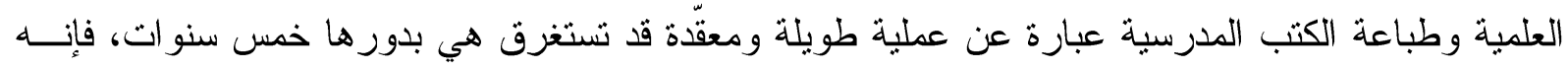

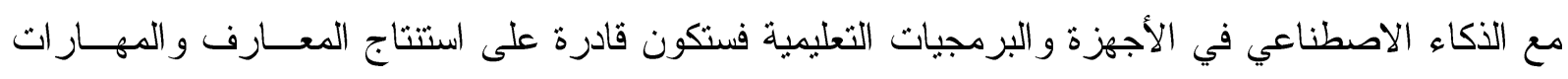

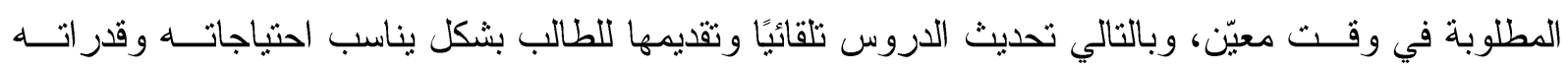

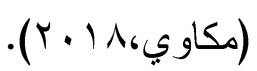

\section{رابعًا: خصائص الذكاء الاصطناعي:}

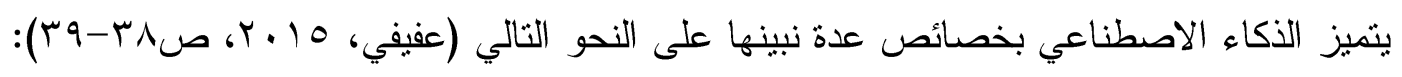

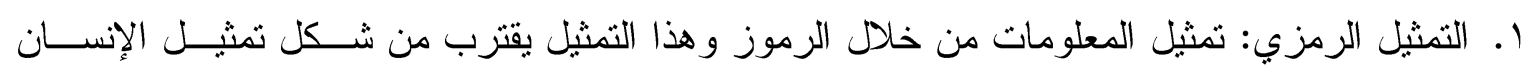

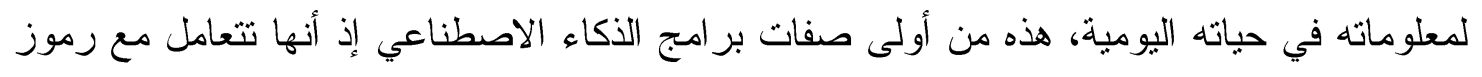

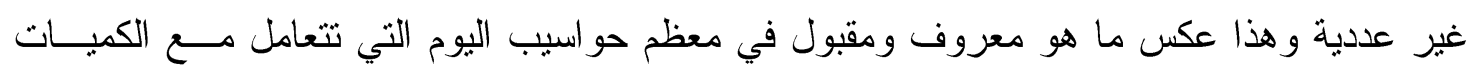
العددية و الأرقام.

r. البحث التجريبي: تتوجه برامج الذكاء الاصطناعي نحو مشاكل لا تتو افر لها حلول يمكن إيجادها تبعا

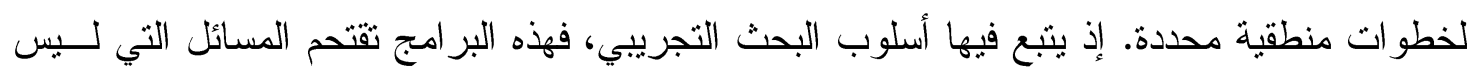

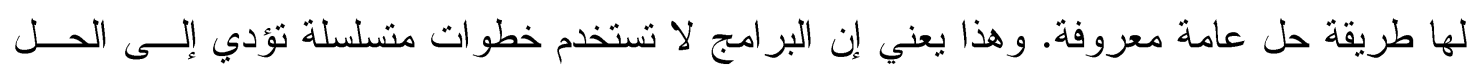

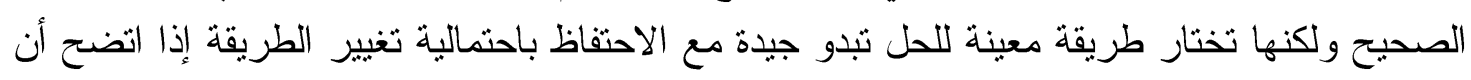
الخيار الأول لا يؤدي إلى الحل سريعًا.

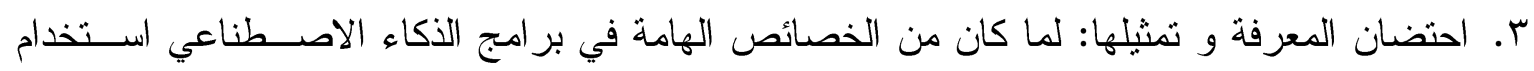

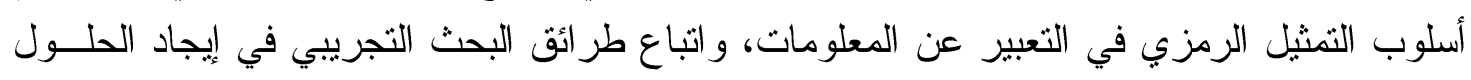

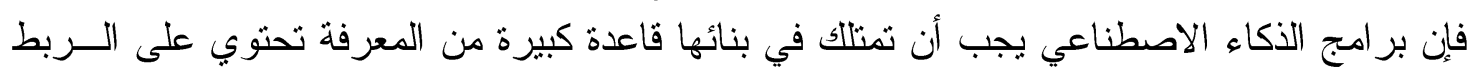

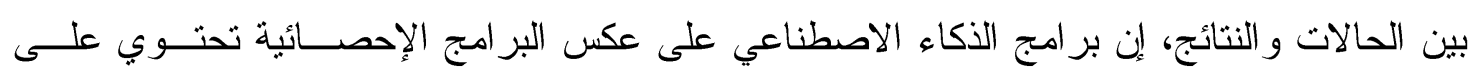

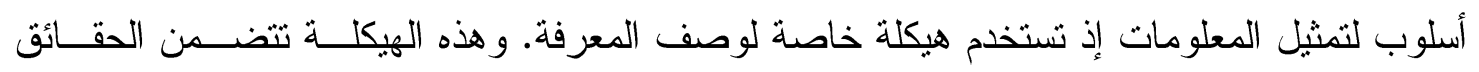
(Facts) و العلاقات بين هذه الحقائق (Relationships) (Knowledge Base) (Rules)

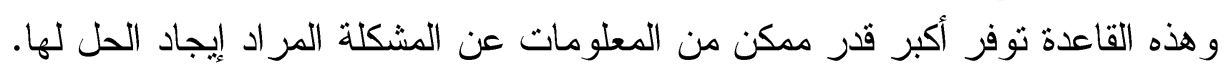

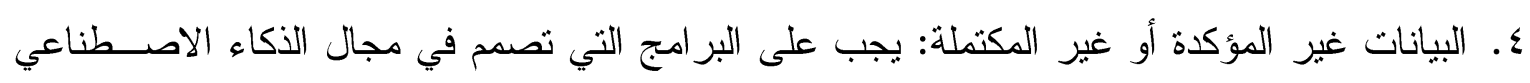

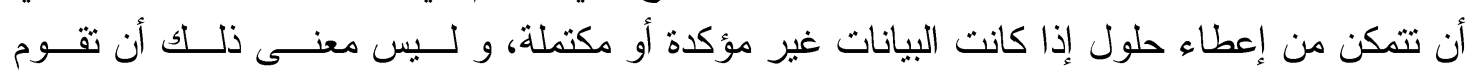

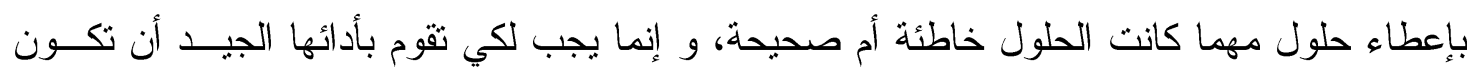

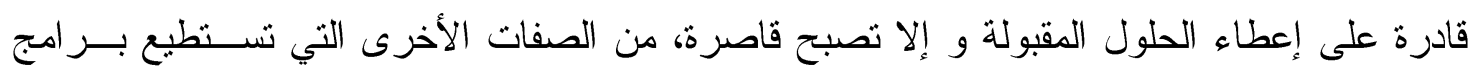




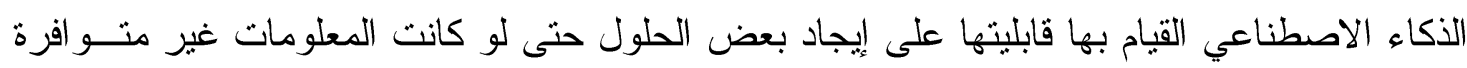

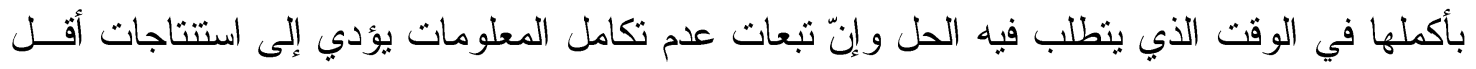

$$
\text { و اقعية أو أقل جدارة. }
$$

0. القدرة على التعلم: تعتبر القدرة على التعلم إحدى مميزات السلوك الذكي و سواء أكان التعلم في البشر

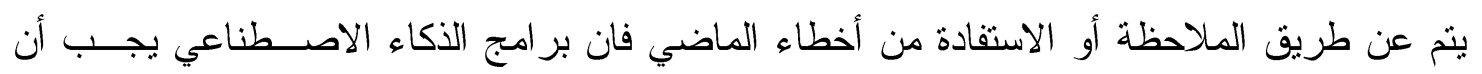

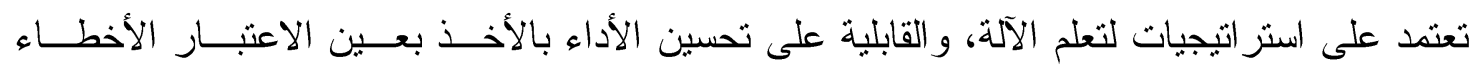

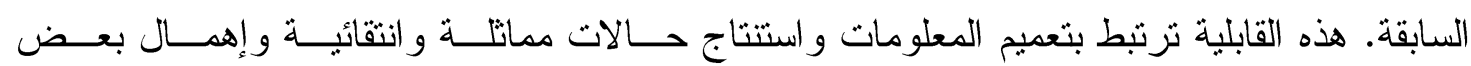

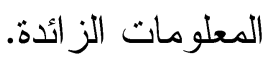

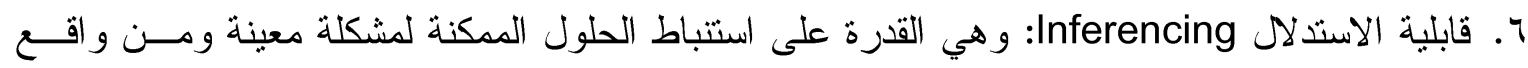

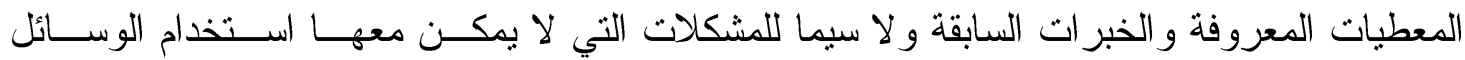

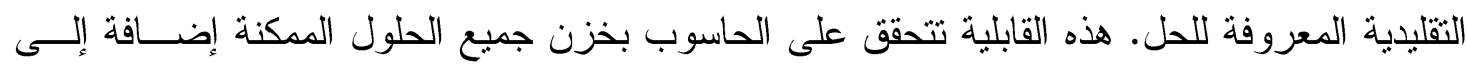
استخدام قو انين أو استر اتيجيات الاستدلال (Inference Rules \& Strategies) وقو انين المنطق.

\section{خامسًا: عيوب الذكاء الصناعي:}

تتمثل مشاكل الذكاء الاصطناعي في النقاط الثالية (1) • Reddy):

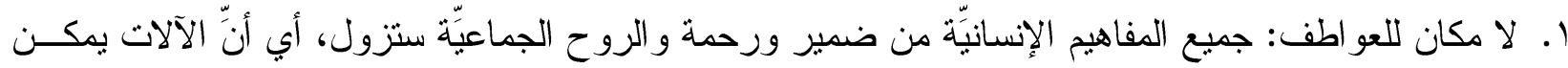

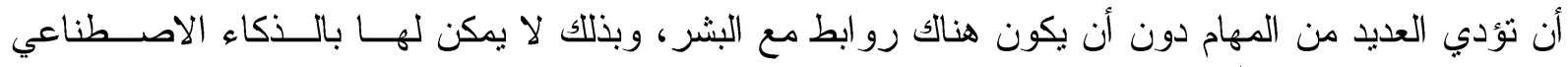
استبدال العلاقات البشريّة. r. البطالة: لا يمكن للإنسان أن بضاهي الآلة من حيث الفاعليّة، وبالتالي ستحل الآلات مكان البشر في المجـالات

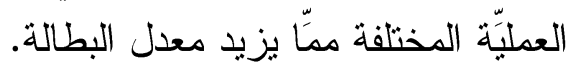
r. التكلفة العالية: العمل في هذا المجال يتطلب مالاً كثيرًا سو اء في عمليّات تصنيع الآلات، وبرمجتها و إصلاحها.

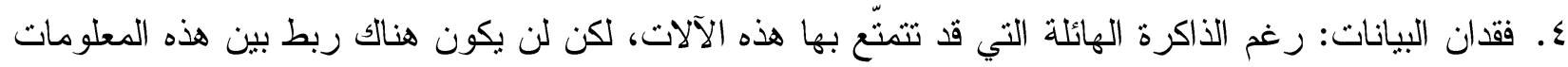

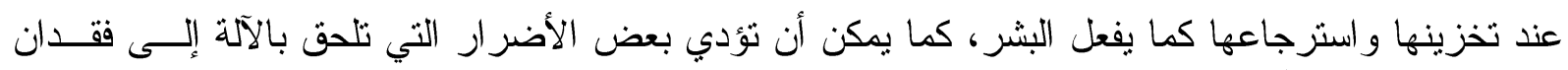
جميع البيانات المخزنّة عليها.

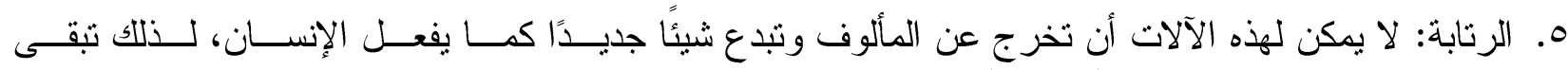

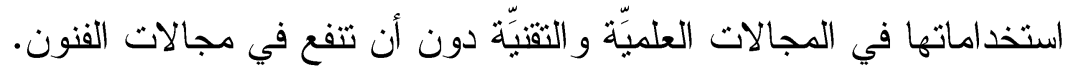

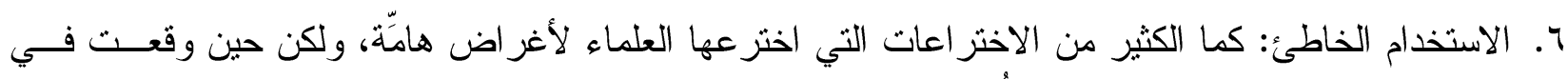

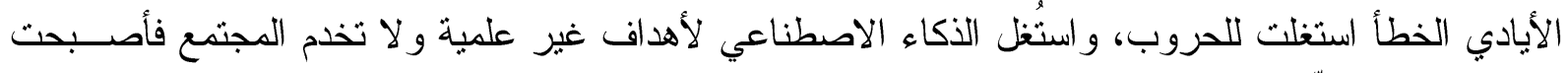
تثنكل تهديدًا حقيقِّا. 
إن اللجوء إلى تطوير عناصر تعليمية كالإدارة المدرسية أو الإشراف التربوي أو التنظيم المنهي أو تحـديث

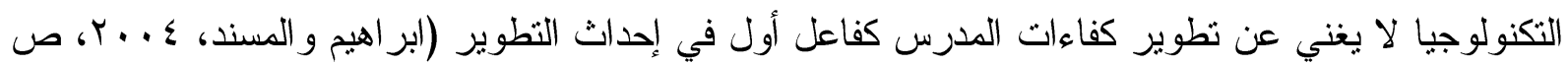

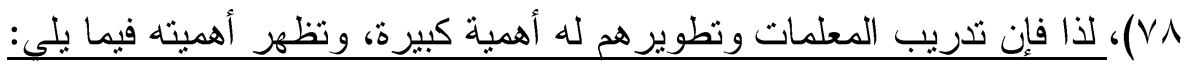

ا. تحسين أداء المعلم مما يؤدي إلى نتائج إيجابية على الطلبة و على المدرسة كمَّا ونوعًا. r. تقليل الحاجة إلى الإشر اف حيث إن زيادة معلومات المعلمات تمكن المعلم من أداء عمله دون الحاجة المتكررة إلى توجيهات المشرف أو قائد المدرسة.

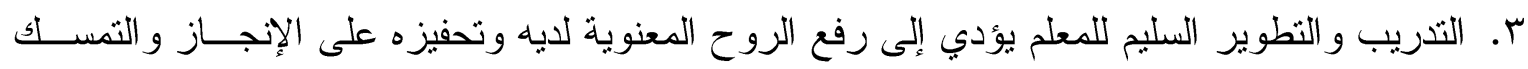
بالعمل.

ع. التذريب ضرورة ملحة للمعلمات الجدد يمكنه من أداء عملهم بطريقة صحيحة. 0. التغير الوظيفي من وقت لآخر بسبب التكنولوجيا والتغيير التنظيمي الناتج عن تغيير تكنولوجي يحتاج

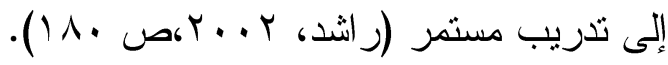

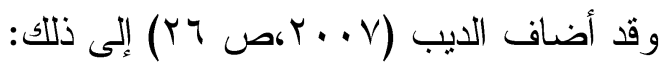

ا ـ التدريب يعتبر الوسيلة الأكثر فاعلية و الأقوى تأثثرًا في صقل وتتمية العاملين بالمدرسة.

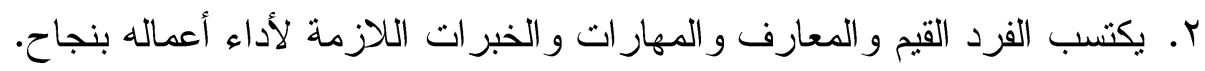
r. يمنح الفرد فرصة الحصول على رصيد ثر اكمي و افر من الخبرات السابقة. ع. يوفر التدريب الكثير من الوقت و الجهد في الحصول على المعارف و المهار ات و الخبرات المطلوبة. ه. يمنح التدريب المعلم القدرة على مو اكبة الجديد والحديث في المجال الذي بعمل فيه. 7. يمنح الفرد القدرة على مو اجهة التحديات الحالية و المتجددة التي تو اجه عمله.

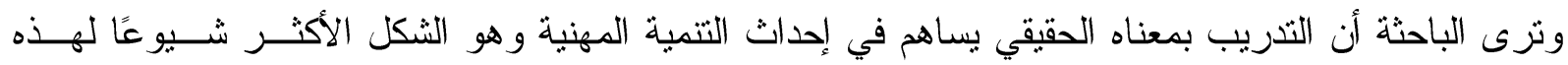

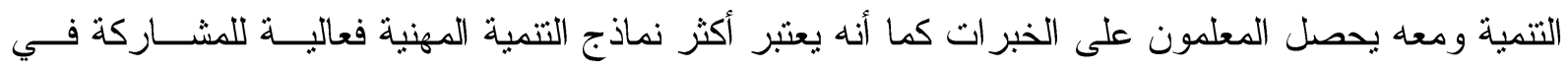

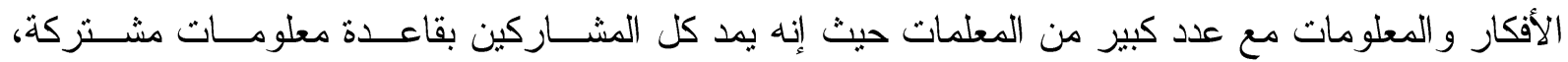
وتز ادفات شائعة ومن هنا تبرز أهمية التدريب.

\section{ثانبًا: أهمبة تحدبد الاحتباجات التدريبية:}

أدى ظهور الاحتياجات التدريبية إلى سرعة الاستجابة و الاهتمام المتز ايد لبر امج تتمية المعلمات و أصبحث لتلك

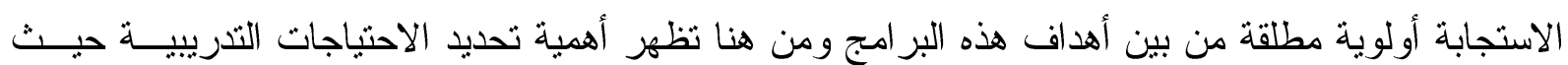

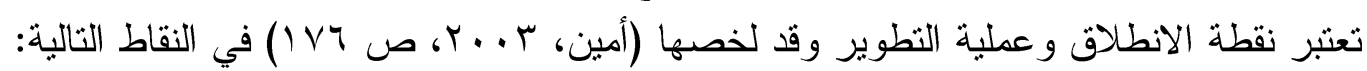

ا ـ تفعيل البر امج التدريبية ورفع كفاءتها من خلال تحديد نوعية محتوى البر امج التدريبية. r. توظيف المعلومات الناتجة من البرامج التعليمية في التتبؤ باحتباجات المسنقبل. r. توفير الجهد و الوقت و التكلفة عند تتفيذ البر امج التدرييية.

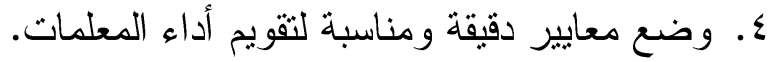




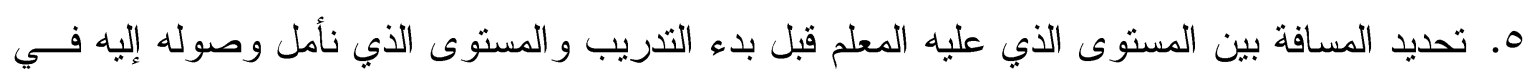
النهاية.

\section{ثالثًا: معوقات تحدبد الاحتباجات التخريبة للمعلمات:}

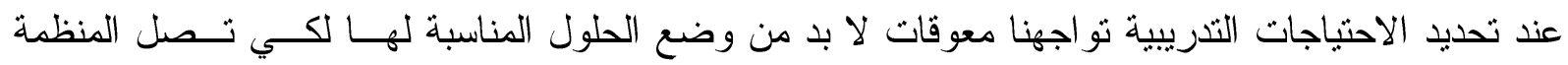

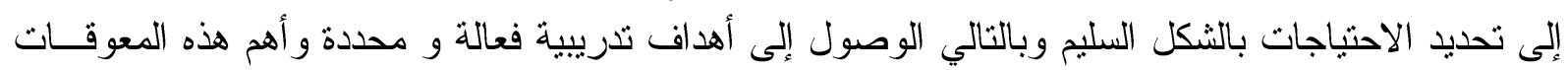

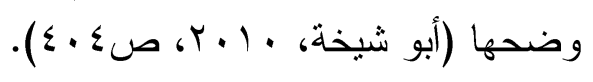

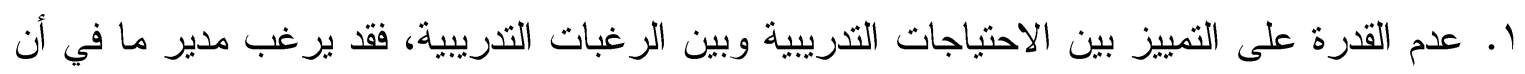

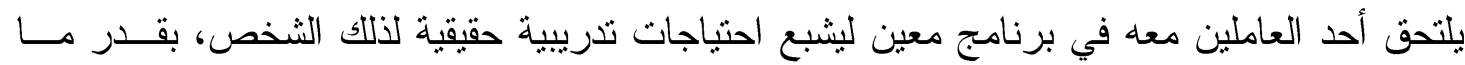

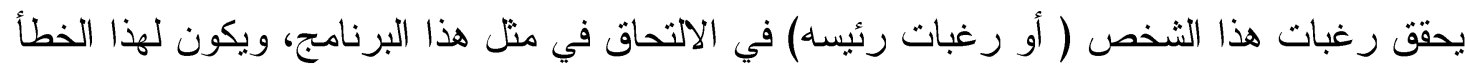

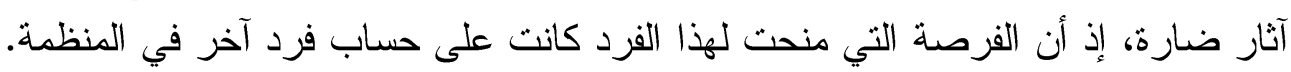

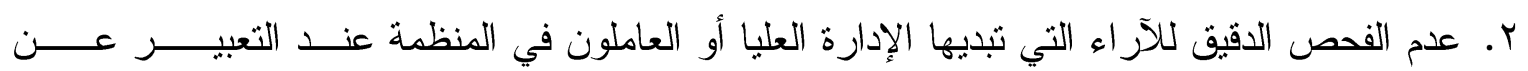

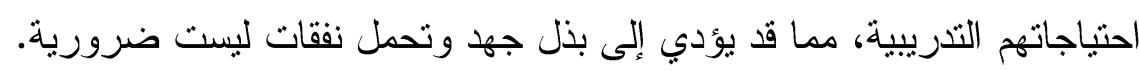

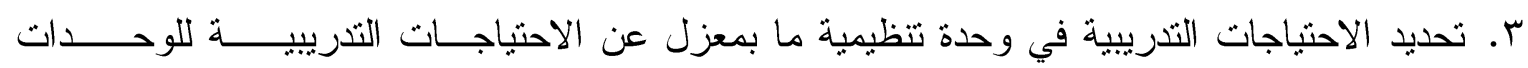

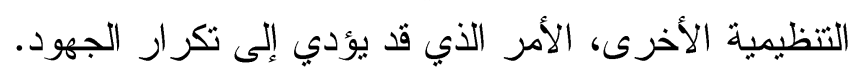

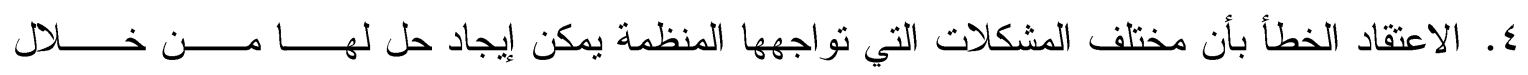

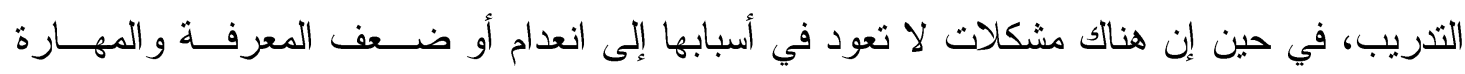

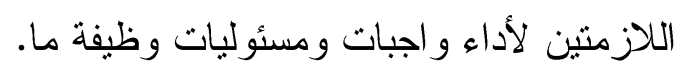
0. الاعتماد على الحس و التخمين و التقليد لمنظمات أخرى بدلًا من إجر اء تحديد للاحتياجات. 7. التزكيز على الاحتياجات التنريبية الحالية و إهمال الاحتياجات التنريبية المستقلية مما يجعـل التحديد

$$
\text { غير دقيق. }
$$

وتضيف الباحثة إلى ما سبق:

1. الاهتمام بالكم دون الكيف عند تحديد الاحتياجات التدريبية. r. r. عدم استخدام الأساليب الحديثة في تحديد وجمع البيانات التدريبية.

المحور الثالث: التنمبة المهينة لقدرات المعلمات:

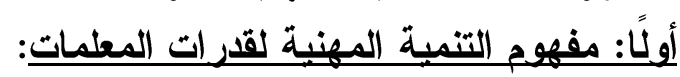

"مجموعة من الأهداف التي تتزجم في وسائل و أنشطة تتخذها المؤسسة لتخطيط وتطوير مستقبل الوظائف لديها

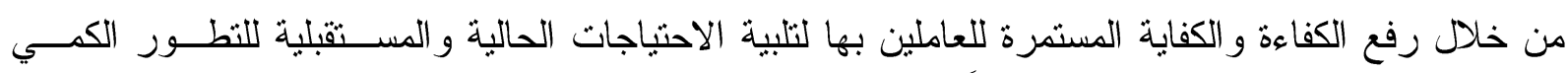

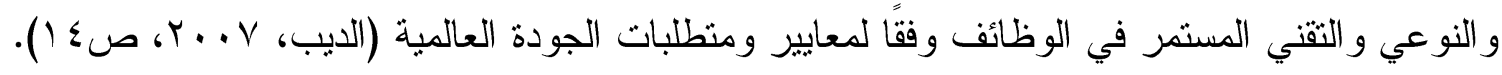




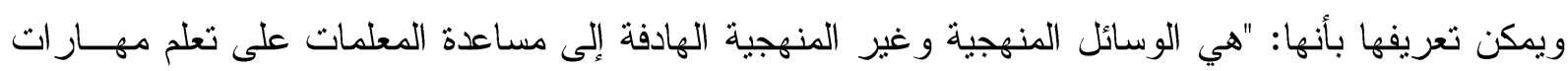

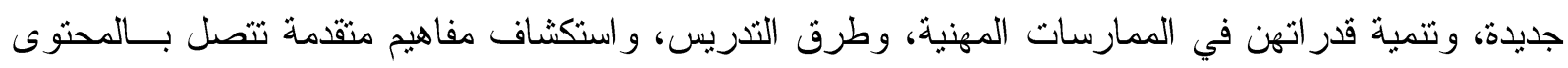
و المصادر و الطر ائق لكفاءة العمل التنريسي".

وتعرفها الباحثة إجر ائيًا بأنها: "هي عملية حصول المعلمة على المهار ات و المعلومــات و الأســاليب التزبويـــة

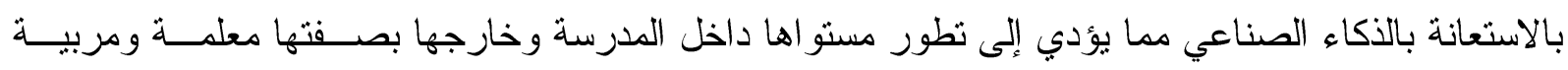

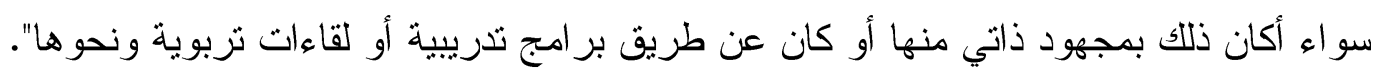

ثانيًا: مبررات التنمية المهينية للمعلمات:

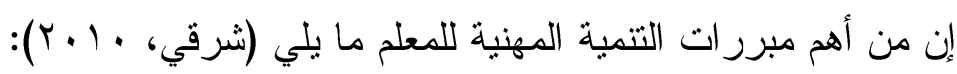
ا. الثورة المعرفية و التفجر المعرفي في جميع مجالات العلم و المعرفة وقد ساهمت ثورة الاتصالات فـي في لفي انتثار ها و اتساع نطاقها.

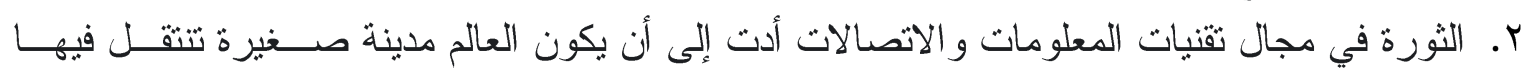
المعارف المستجدة بسر عة هائلة. r. تعددية أدو ار المعلم وتعدد مسئولياته في المجال التعليمي فبعد أن كان ملقِّاً للمعلومة ومصدر ها أصبح

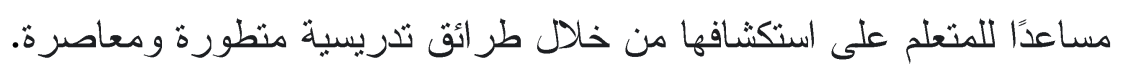

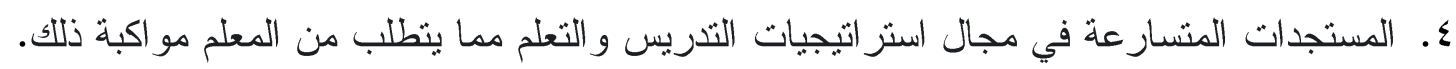

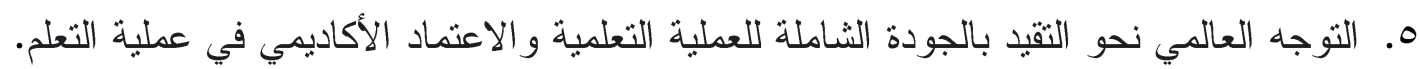

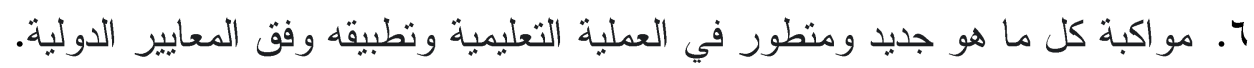

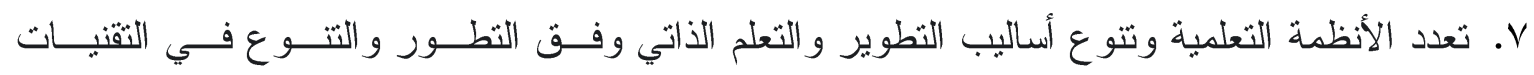
المعاصرة ويجب على المعلم مو اكبة ذلك.

ثالثًا: أهداف التنمية المهنية للمعلم :

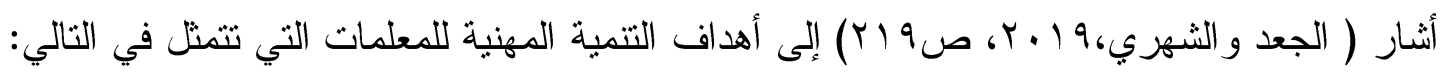

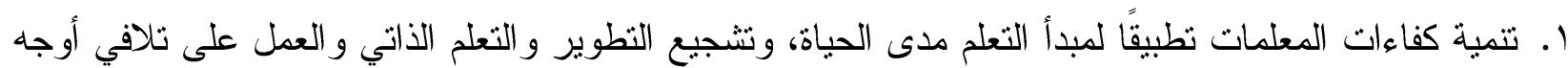

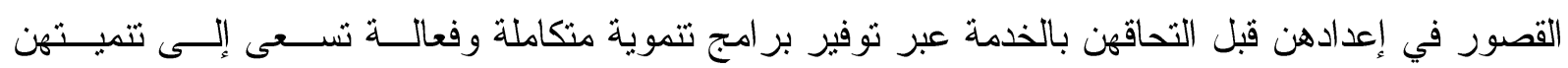

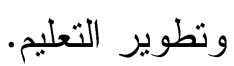

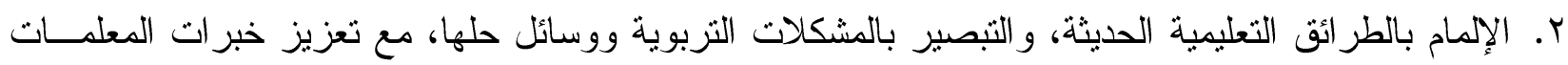

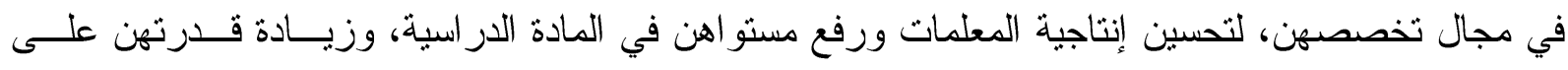

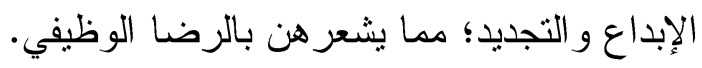

r. التنريب على المناهج المطورة لنقوم المعلمة بالأدوار الموكلة إليها، وتحسين نوعية التعليم حتى يؤثر التندريس

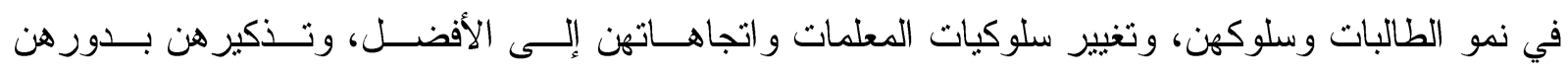
ومسؤولياتهن في العملية التعليمية.

ـ. ـ مساعدة المعلمات حديثات التخر ج للاطّلاع على القو انين و النظم؛ حتى يسنطعن مواجهة المو اقف الجديدة فـي ميدان العمل ولتعزيز ثقتهن بأنفسهن. 


$$
\text { 1. التطوير و التجديد و التحديث في المجال الأكاديمي التخصصي. }
$$

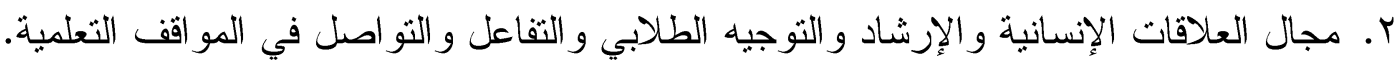

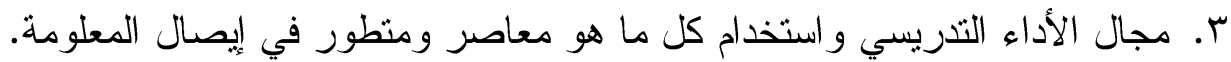

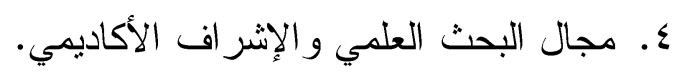
ه. 1.

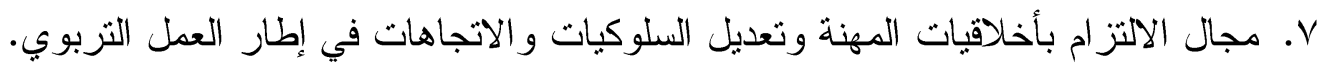

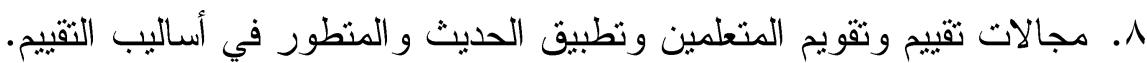

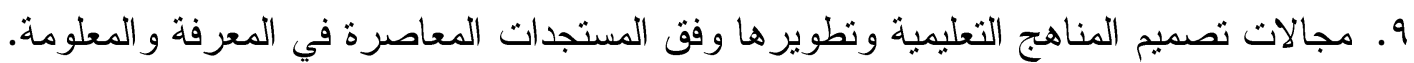
خامسنًا: معوقات التنمية المهنية للمعلمات:

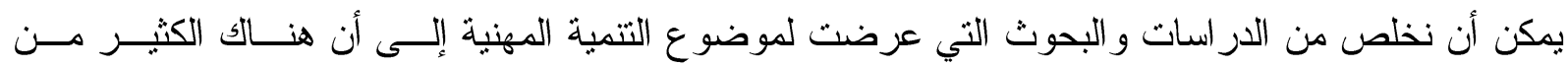
المعوقات التي تتعلق بعملية التتمية المهنية للمعلمات ومن أبرزهات البها ما يلي:

1. عدم كفاية وقت المعلم للتنريب أثناء الخدمة، و لا يوجد نظام و اضح خاص بتنظيم أعمال التدريب و التأهيـلـ

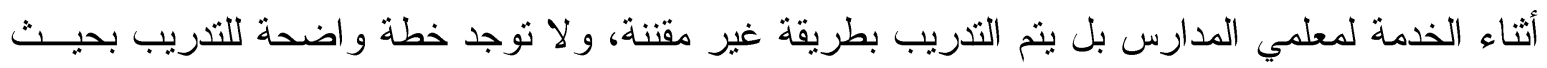

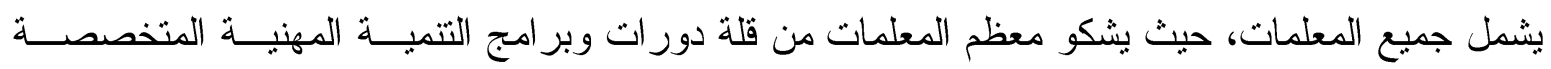

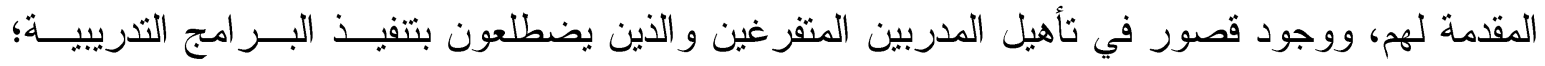

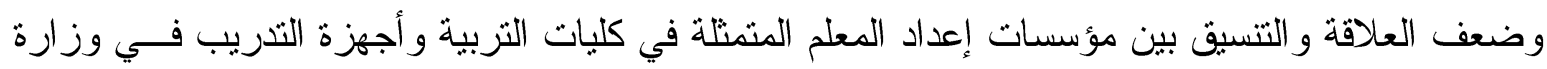

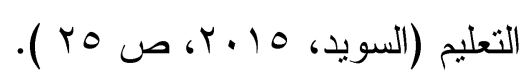

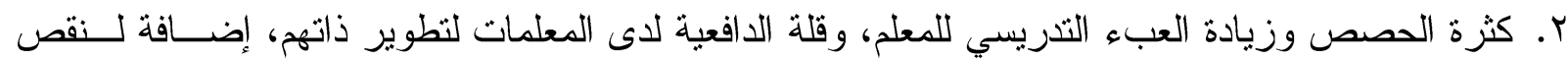

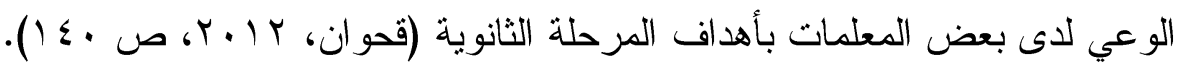
r. ضعف الرضا الوظيفي لاى المعلم مما يضعف اهتمامه بالتتمية المهنية، وضعف اهنمام المعلمــات بتبــادل

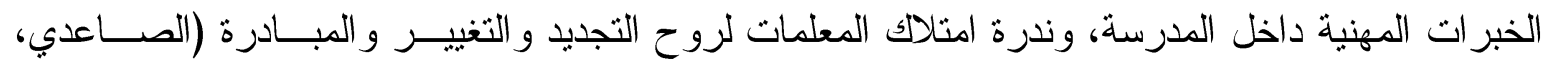
. (r.)

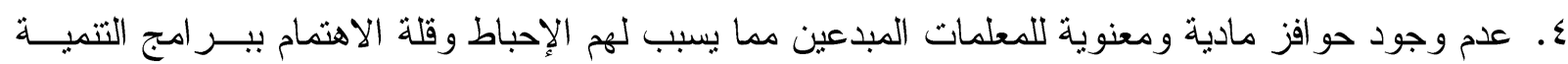

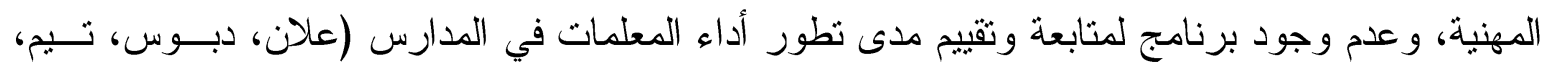

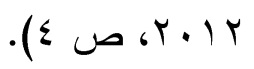

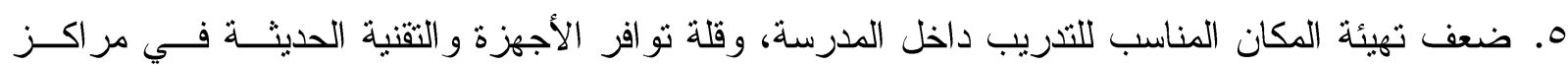

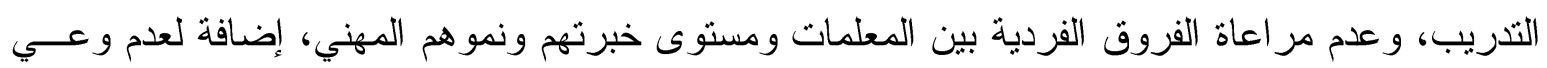

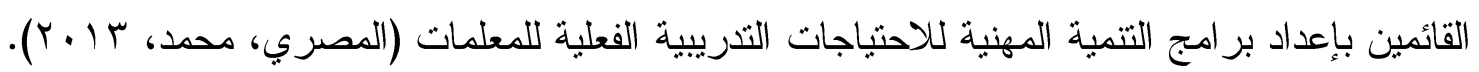


ا. دراسة الشمري (19 • ب) بعنوان: "دور التعلم الرقمي في التتمية المهنية للمعلمات"

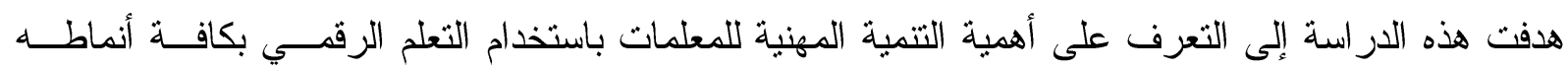

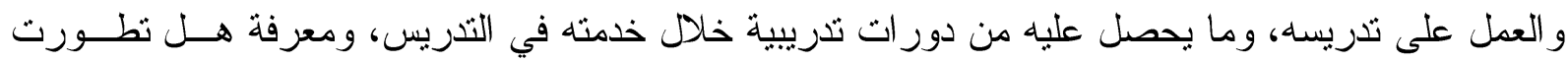

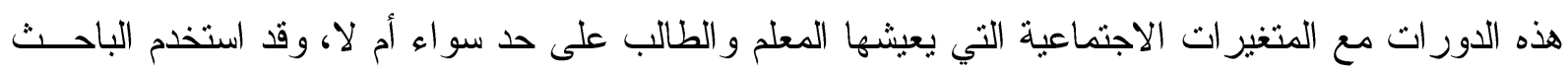

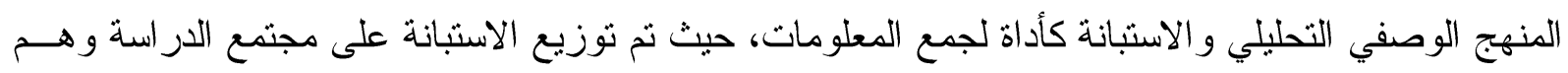

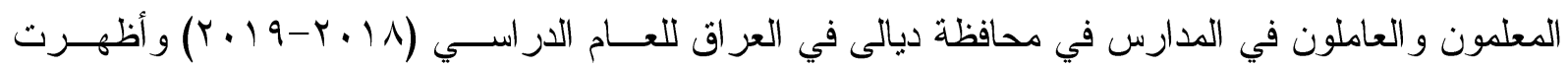

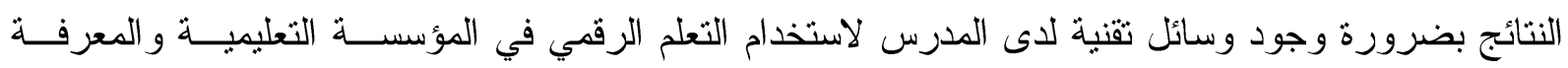
الكاملة في كيفية استخدام هذه التقنية الحديثة.

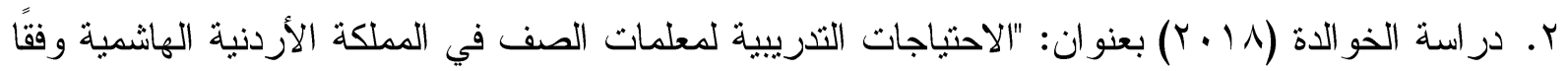
لأدو ارهن المستقبلية في ظل اقتصاد المعرفة:

هدف هذا البحث إلى تحديد الاحتباجات التصريبية لمعلمات الصف وفقًا لأدو ارهن المستقبلية في ظــل اقتصــاد

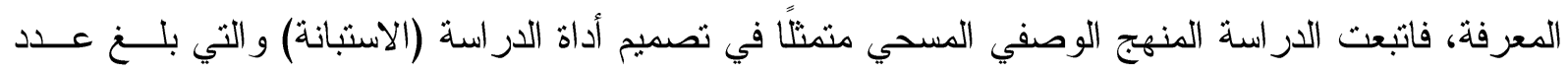

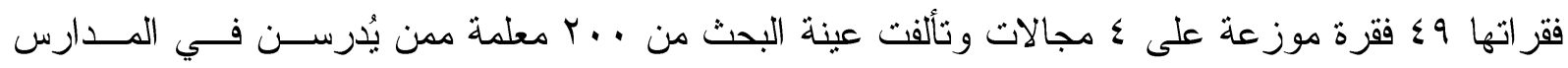

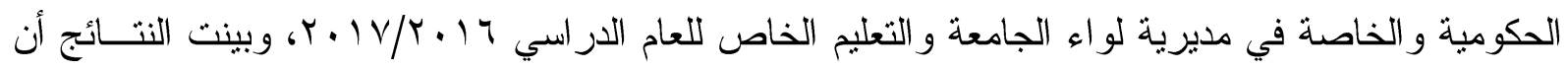

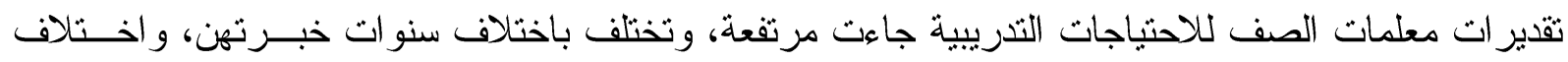

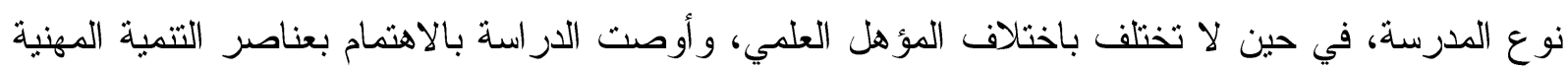

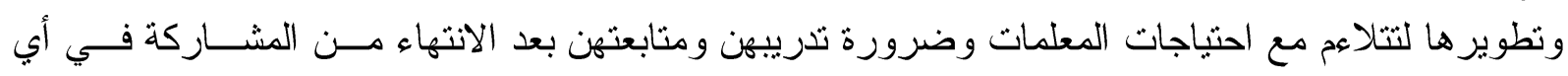
دورة أو برنامج تدريبي للتأكد من مدى استفادتهن وقدرتهن على التهات النطبيق الفعلي.

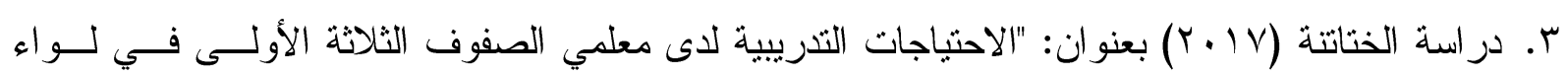

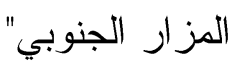

هدفت الدراسة الحالية إلى التعرف على الاحتياجات التنريبية اللازمة لمعلمي الصفوف الثلاثة الأولى، ولتحقيق

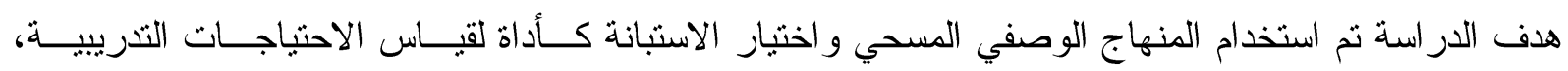

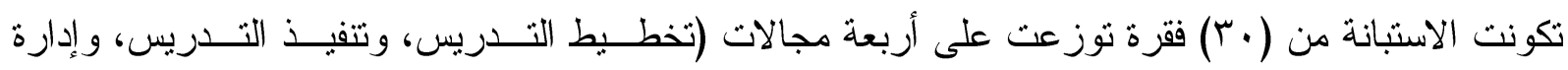

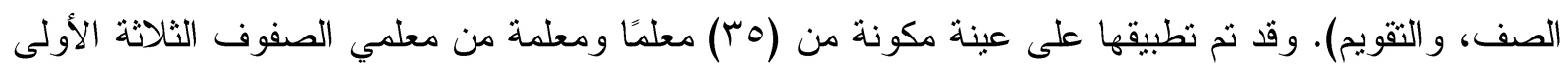

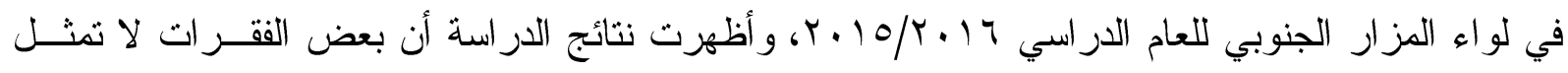

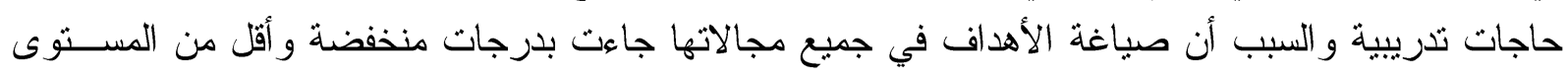

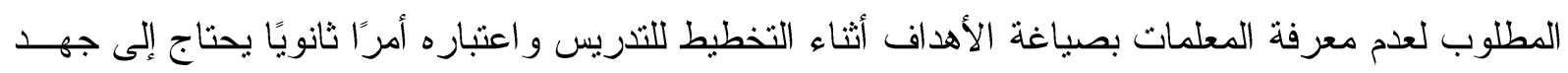

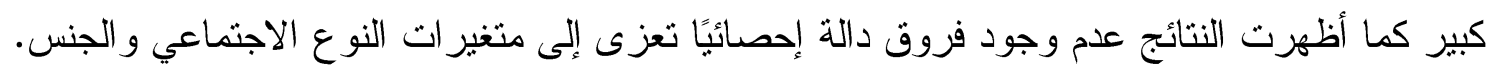

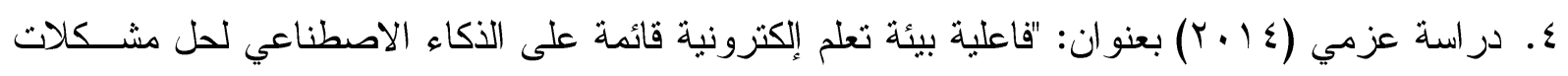

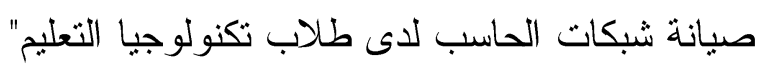

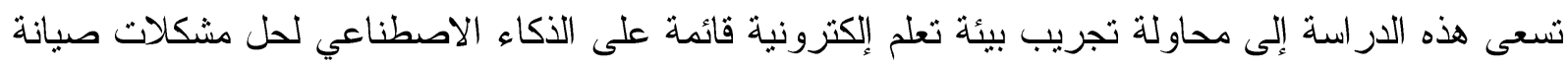

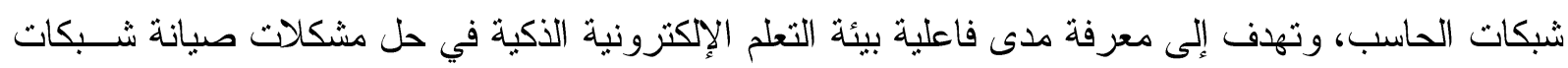




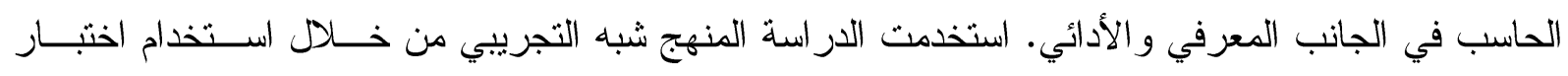

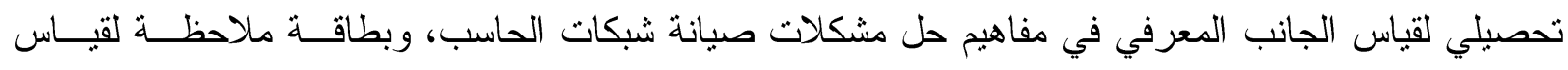

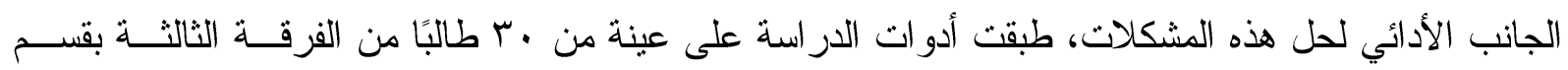

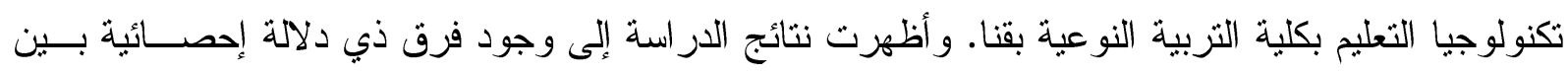

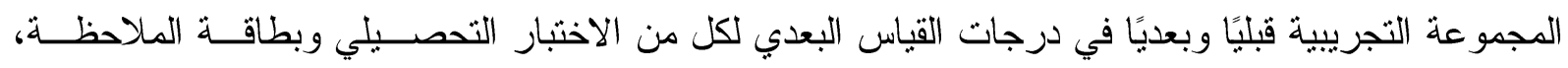

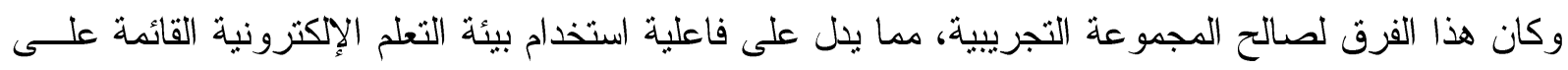

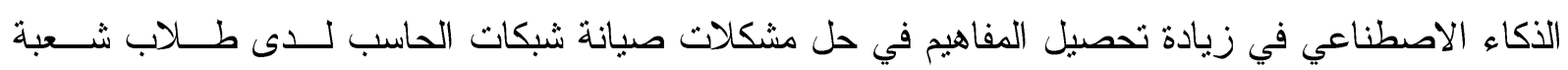
تكنولوجيا التعليم بكلية التزبية النوعية.

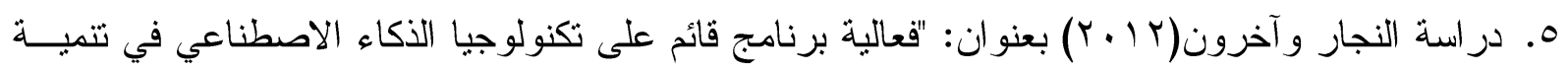

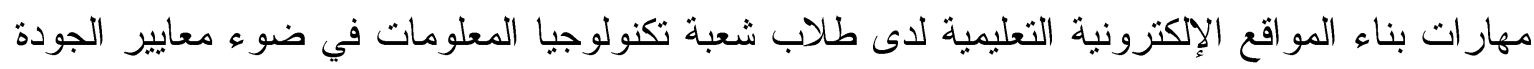

الثاملة"

تهاف الدر اسة إلى التعرف على فعالية برنامج تعليمي ذكي في تتمية مهار ات بناء المو اقع الإلكترونية التعليمية

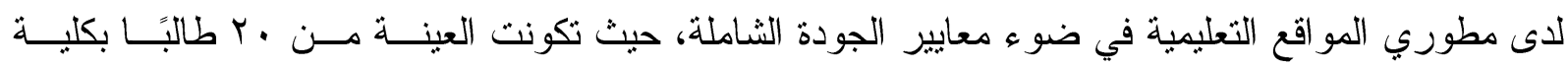

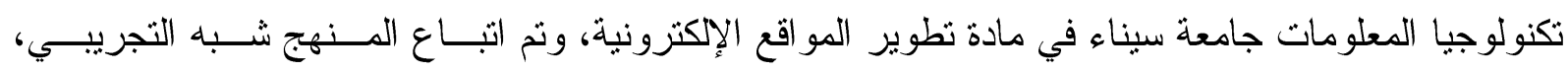

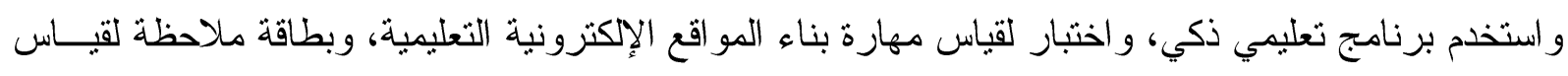

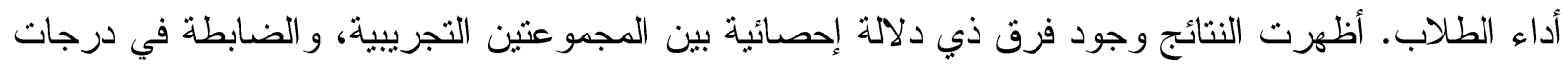

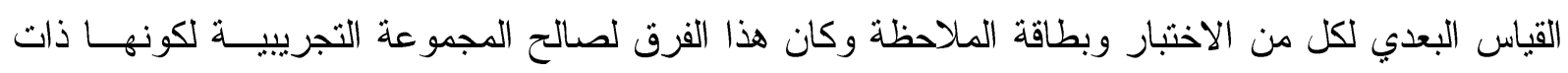

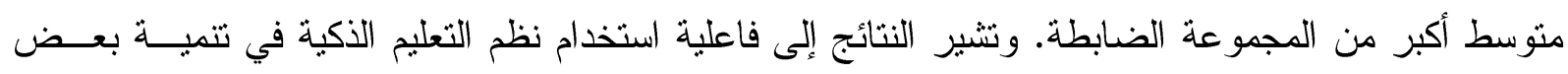
مهار ات طلاب شعبة تكنولوجيا المعلومات في بناء المو اقع الإلكترونية.

\section{التعقيب على الدر اسات السابقة:}

من خلال العرض السابق لبعض الدراسات السابقة المتعلقة بموضوع الدراسة الحالية سيتم استخلاص ما يلي:

\begin{tabular}{|c|c|c|c|c|c|c|}
\hline 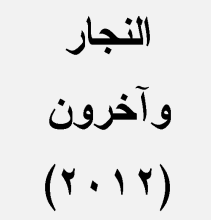 & 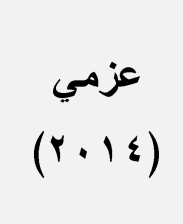 & 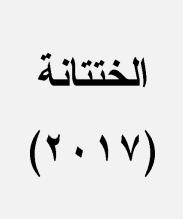 & الخو الدة & 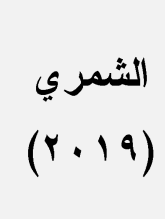 & الدراسة الحالية & المقارنة \\
\hline 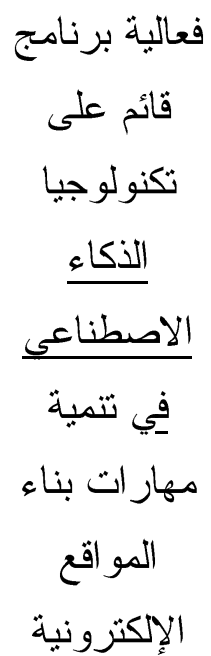 & فاعلية بيئة & 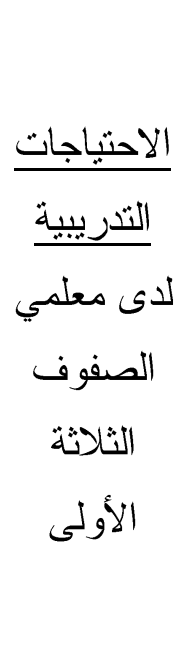 & 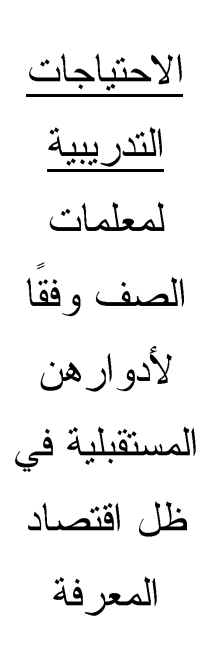 & اللمقدي في المتية & 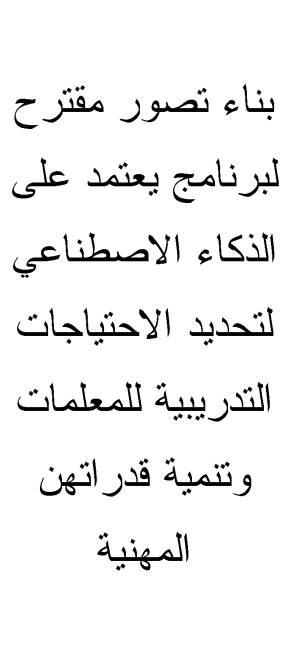 & الالهدف من \\
\hline
\end{tabular}




\begin{tabular}{|c|c|c|c|c|c|c|}
\hline \multicolumn{5}{|c|}{ نوال بنت صويلح حمدان الجهني } & \multicolumn{2}{|c|}{ لعدد التاسع عشر يناير 9 | . r } \\
\hline التوع التيمية في معايير & شبكات & & & & & \\
\hline شبه التجريبي & شبه & الوصفي & الوصفي & الوصفي & ا ـ ـ التحليل. & المسنهذج \\
\hline التحصيلي الاختبار & الاختبار & الاستبانة & الاستبانة & الاستبانة & الاستبانة & ألدو استة \\
\hline الطلاب & 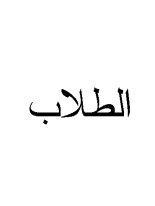 & المعلمات & المعلمات & العداملين في & المعلمات & وجنمع الدر اسية \\
\hline
\end{tabular}

ثُالثاً: الاستفادة من الار اسات السابقة: وبعد إطلاع الباحثة على الدراسات السابقة التي تتاولت التقويم التكويني من مختلف جوانبه، فقد استفادت

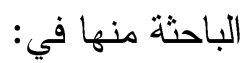
1. إعداد الإطار النظري، و الاطلاع على الأدبيات المتعلقة بالموضوع.

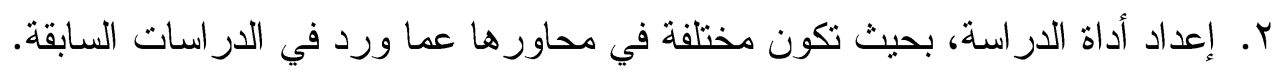
r. استخدام الأساليب الإحصائية المناسبة.

الطريقة والإجر اعات:

منهج الدارسة: استخدمت الباحثة منهجين للارسة: ا. المنهج الوصفي التحليلي: حيث استخدمت الباحثة المنهج الوصفي التحليلي من أجل التعرف على معوقات تحديد الاحتياجات التدريية للمعلمات، ومعوقات تنمية القدرات المهنية للمعلمات من وجهة نظرهن. ويعرف المنهج الوصفي التحليلي: "طريقة منتظمة لدر اسة حقائق راهنة، متعلقة بظاهرة أو موقف أو أفر اد، أو

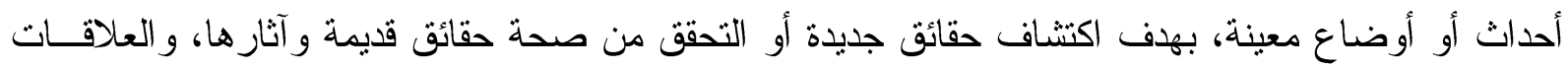

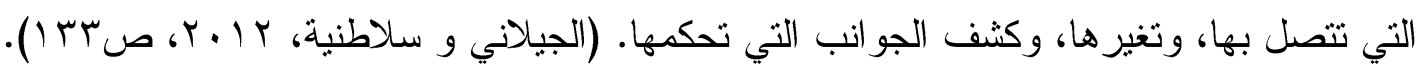

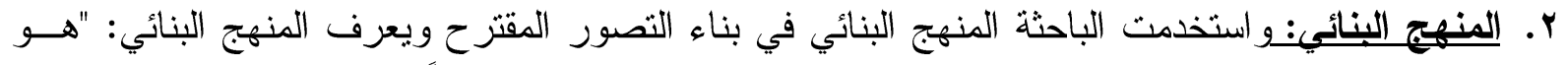
المنهج المنبَع في إنشاء وتطويرِ برنامجٍ أو هيكل معرفيٍٍ جديد لم يكن معروفًا من قبّل؛ كبناء وحدة در اسيَّة

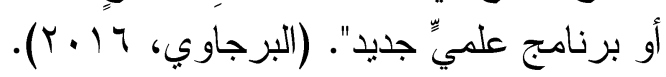




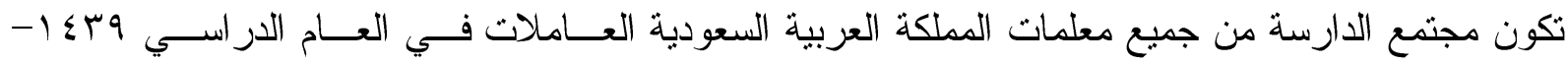

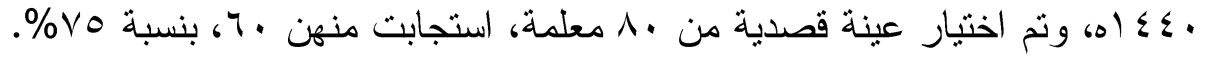

$$
\text { جدول رقم (1) : نوزيع عينة الدر اسة حسب متغير ات الدر اسة }
$$

\begin{tabular}{|c|c|c|c|}
\hline النسبة & العدد & الفئات & المتغير \\
\hline$\ldots \ldots \%$ & . & دبلوم & \multirow{4}{*}{ المؤهل العلمي } \\
\hline A.... & $\varepsilon \lambda$ & بكالوريوس & \\
\hline$r \ldots \ldots \%$ & ir & ماجستير فأكثر & \\
\hline$\%$ & 7. & المجموع & \\
\hline $0 . \ldots \%$ & $r$ & أقل من ه سنوات & \multirow{4}{*}{ سنوات الخدمة } \\
\hline 纟八.ru\% & rq & من 0- . ـ سنوات & \\
\hline$\leq 7.7 \vee \%$ & $r \wedge$ & أكثر من · ا سنو ات & \\
\hline$\%, \ldots$ & 7. & المجموع & \\
\hline
\end{tabular}

وتم اختبار (·r) استبانة عشو ائيًا لقياس الصدق و الثبات، تم تضمبنها في تحليل النتائج بسبب تمنـع الاسـتبانة

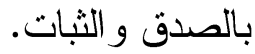

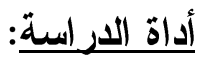

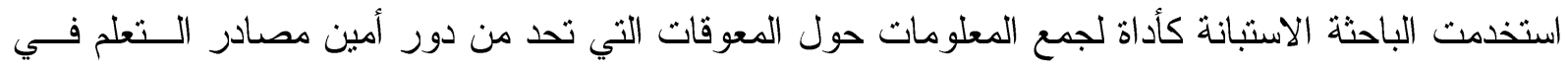

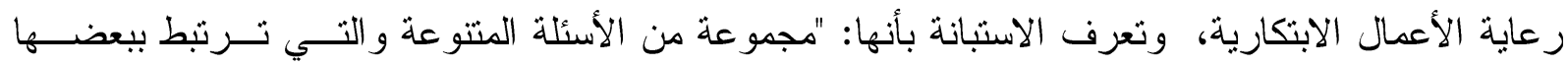

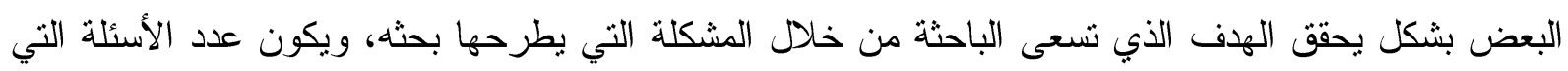

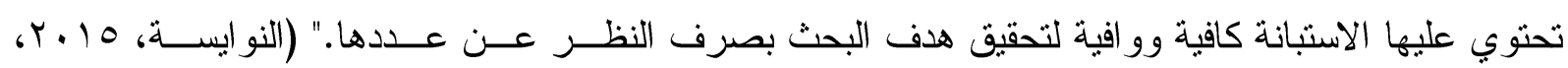
(V9 ص

وقد استخدمت الباحثة مقياس ليكارت الخماسي لقياس استجابات أفراد عينة الدراسة لفقرات الاسـتبانة حسـبـ

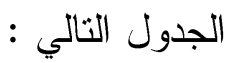

جدول رقم (ץ) مقياس ليكارت الخماسي

\begin{tabular}{|c|c|c|c|c|c|}
\hline كبيرة جدا & كبيرة & متوسطة & قليلة & قليلة جدا & الاستجابة \\
\hline 0 & $\varepsilon$ & r & $r$ & 1 & الدرجة \\
\hline
\end{tabular}

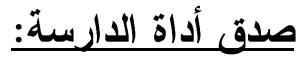

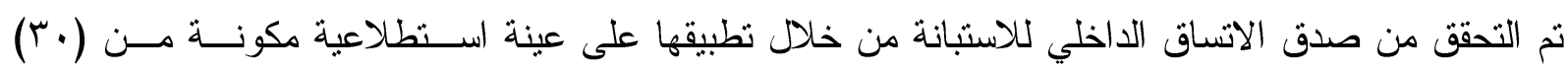
استجابة، وقم تم حساب معامل الارتباط بيرسون بين درجة كل فقرة ومجموع درجات الاستبانة. 
جدول رقم (ץ) معاملات الارتباط بين كل فقرة من فقرات المقياس الأول (معوقات تحديد الاحتياجات

(التدريبية للمعلمات)

و الارجة الكلية للمقياس لمعلى

\begin{tabular}{|c|c|c|c|}
\hline 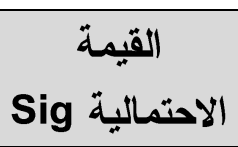 & معامل الارتباط & 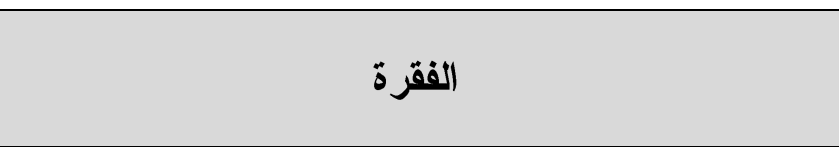 & $p$ \\
\hline$\ldots 1$ & .0 & قللة ربط تقييم أداء المعلم بالاحتياجات التنرييية & 1 \\
\hline$\cdots$ & $\therefore v \cdot$ & عدم تعاون المعلمات في تحديد احتياجاتهم التدريبية & r \\
\hline$\cdots$ &..$\vee 9$ & ضعف في موضو عية قائد المدرسة في تحديد الاحتياجات & $r$ \\
\hline$\ldots$ &. .74 & عدم تحديد فجوات الأداء وفقا لأهداف المعلمات & $\varepsilon$ \\
\hline$\cdots$ & $\cdot . \wedge$ & عدم قناعة المعلمات بأهمية تحديد الاحتباجات التنريبية & 0 \\
\hline$\cdots$ & . . & شعور المعلم بكفايته من الاحتياجات التدريبة & 7 \\
\hline
\end{tabular}

$\alpha=$ =. م الارتباط دال إحصائيا عند مستوى دلالة

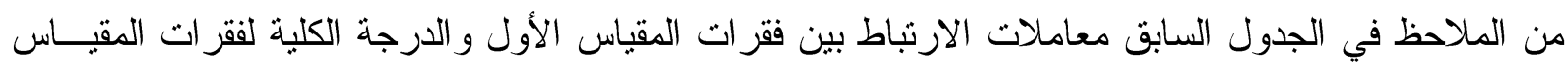

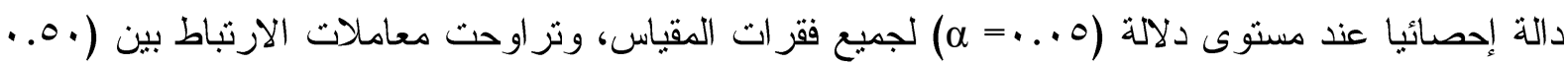

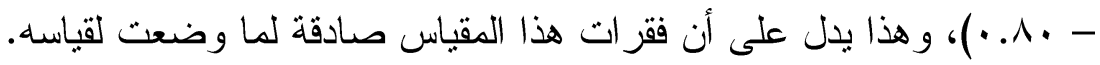

جدول رقم (؟) معاملات الارتباط بين كل فقزة من فقرات المقياس الثاني (معوقات تتمية القدر ات المهنية للمعلمات)

و الدرجة الكلية للاستبانة

\begin{tabular}{|c|c|c|c|}
\hline القيمة الاحتمالية & معامل الارتباط & 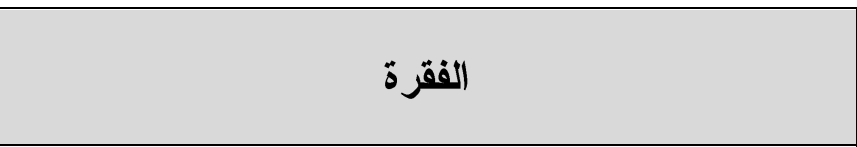 & b \\
\hline$\ldots$ &.$\vee$. & افتقار بر امج التتمية المهنية للخبر ات العالمية المعاصرة. & 1 \\
\hline$\ldots$ &.$V V$ & عدم القدرة على وضع خطة زمنية لنطوير الذات. & r \\
\hline$\cdots$ &. .71 & ندرة إقامة برامج للتنمية المهنية داخل المدرسة. & r \\
\hline$\ldots$ &.$V r$ & كثرة الأعباء الأسرية للمعلمة. & $\varepsilon$ \\
\hline$\cdots$ &. .70 & هدر وقت التنريب في مناقشات جانبية لا تتصل بالبرنامج & 0 \\
\hline$\ldots$ &. .74 & ندرة مصادر التعلم الذاتية للمعلمة في المدرسة. & 7 \\
\hline
\end{tabular}

$$
\alpha=\text { =. الارتباط دال إحصائياً عند مستوى دلالة }
$$

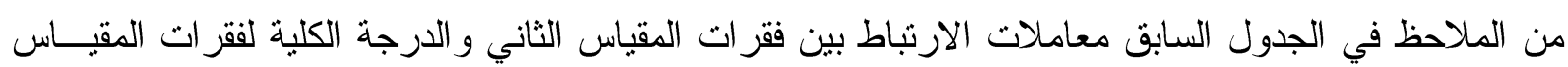
دالة إحصائيا عند مستوى دلالة (م. ...

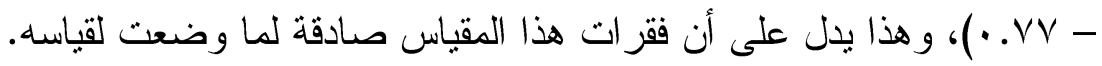


ثبات أداة الدر اسة: وقم ثم استخدام معامل ألفا كرونباخ لاختبار ثبات الاستبانة، وبلغ معامل ألفا كرونباخ حسب حمب الجن

\begin{tabular}{|c|c|c|}
\hline معامل ألفا كرونباخ & عدد الفقرات & المقياس \\
\hline. . 0 & 7 & معوقات تحديد الاحتباجات التنريبية للمعلمات \\
\hline.$V V$ & 7 & معوقات تتمية القدر ات المهنية للمعلمات \\
\hline
\end{tabular}

من الملاحظ في الجدول السابق أن معامل ألفا كرونباخ يزيد عن ه V..، و وذا يدل على ثبات المقياسين، وهذا يجعل الباحثة مطمئنة لتحليل نتائج الاستبانة وتفسير هان.

\section{نتيائج اللارسة:}

المحك المعتمد: نم اعتماد المحك الثالي في تحليل ودارسة نتائج السؤ ال الأول و الثاني: جدول رقم (0) المحك المعتمد في الدراسة

\begin{tabular}{|c|c|c|}
\hline درجة التو افر & الوزن النسبي المقابل له & طول الخلية \\
\hline قليلة جدًا & $\%$ \% - \%r. & $1 . \wedge-1$ \\
\hline قلبلة & أكبر من צr\% - \% \% & أكبر من 1.1 - Y r. \\
\hline منوسطة & أكبر من \% \% \% - \% & 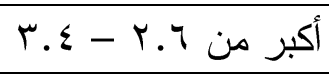 \\
\hline كبيرة & 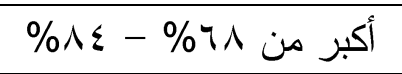 & أكبر من ع.r - - \\
\hline كبيرة جدًا & أكبر من ع^\% - ... (1) & أكبر من Y. \\
\hline
\end{tabular}

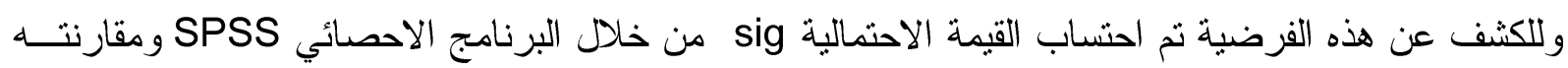

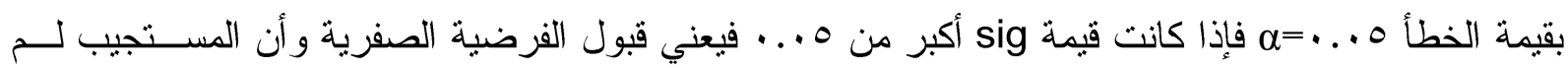

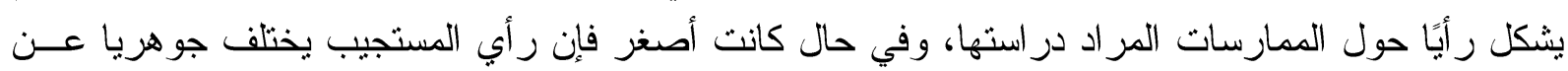
الدرجة المتوسطة وبالثالي يكون قد شكل رأيا حول الممارسات المر اد داد در استها.

الإجابة على السؤال الأول: "ما درجة معوقات تحديد الاحتياجات التنديبية للمعلمات من وجهة نظرهن؟" ولالإجابة على هذا السؤال تم تحليل فقرات المقياس الأول وفق المحك المعتمد في الدراســـة وكانــت النتــائج كالتالي:

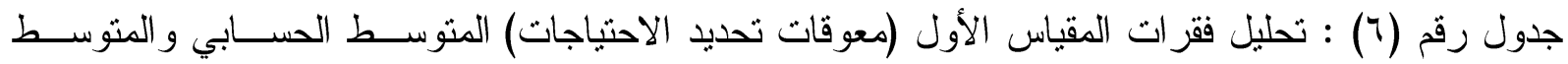

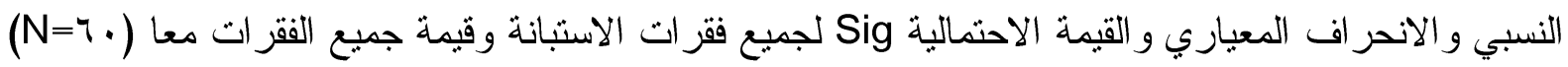

\begin{tabular}{|c|c|c|c|c|c|c|}
\hline الحكم & تليب & الاحتمالية & الانحر & النسبي & الحسابي & الفقر ات \\
\hline كبيرة & r & $\ldots$ & $1 . .1$ & VY...\% & r.ఛ. & قلة ربط تقييم أداء المعلم بالاحتياجات \\
\hline
\end{tabular}


نوال بنت صويلح حمدان الجهني

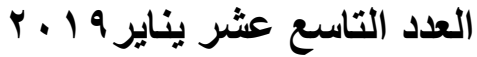

\begin{tabular}{|c|c|c|c|c|c|c|c|}
\hline الحكم & 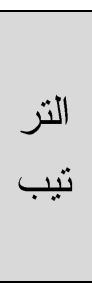 & الاحتمالية & الانحر & المتسبي & | الحسابي & الفقر ات & r \\
\hline متوسطة & 7 & $.0 r$ & I.r. & $0 \wedge . . . \%$ & r.q. & 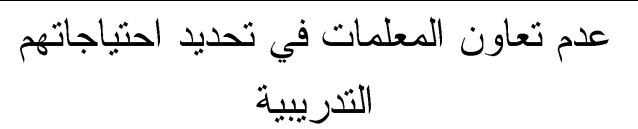 & $r$ \\
\hline متوسطة & 0 & $.0 r$ & I.r. & тr...\% & r.l. & ضعف في موضوعية الاحتياتد المدرسة في & $r$ \\
\hline كبيرة & 1 & $\ldots$ & $1 . r \varepsilon$ & Vr.rr\% & r.tr & عدم تحديد فجو ات الأداء وفقا لأهداف & $\varepsilon$ \\
\hline منوسطة & $\varepsilon$ &.$r$. & I.r. & $\tau \leqslant \ldots \%$ & r.r. & عدم قناعة المعلمات بأهمية تحديد & 0 \\
\hline منوسطة & $r$ &. $.1 \varepsilon$ & I.r. & Tะ.TV\% & r.rT & شعور المعلم بكفايته من الاحتباجات & 7 \\
\hline منوسطة & & $\ldots 1$ & $\therefore \vee 99$ & $70.0 . \%$ & r.rA & الدرجة الكلية للمقياس الأول & \\
\hline
\end{tabular}

يتضح من الجدول السابق ما يلي:

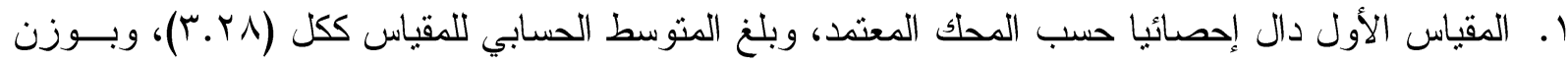

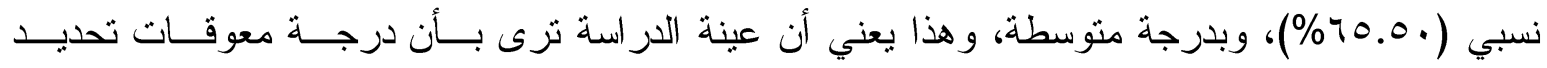

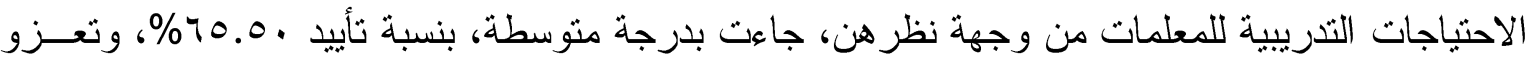

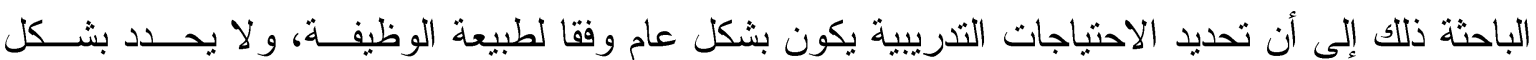
فردي لكل معلمة.

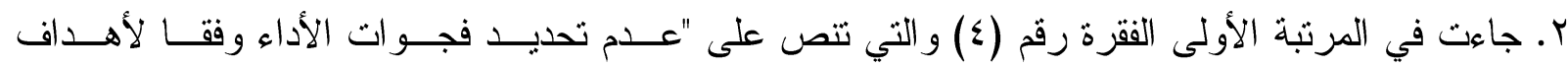

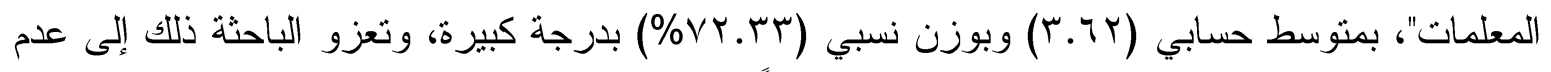

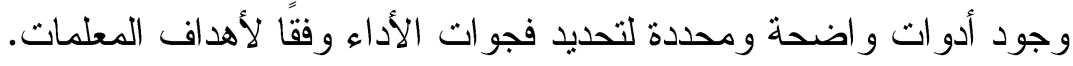

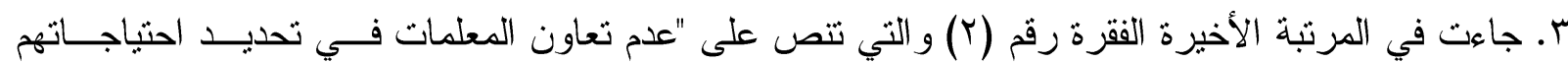

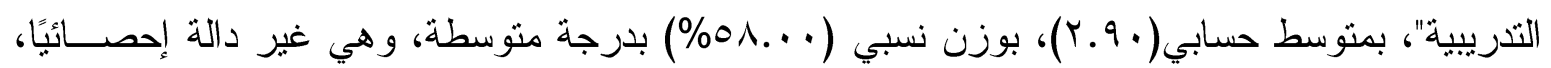

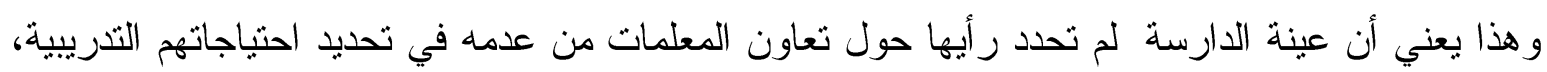

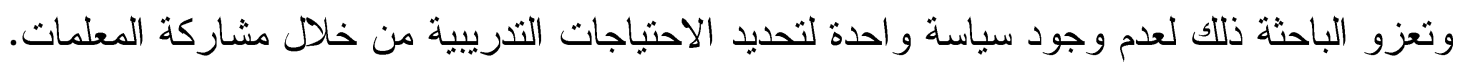

الإجابة على السؤال الثاني: "ما درجة معوقات تتمية القدرات المهنية للمعلمات من وجهة نظرهن؟" وللإجابة على هذا السؤال تم تحليل فقرات المقياس الثاني وفق المحك المتثد في الدراســة وكانــت النتـائج

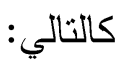

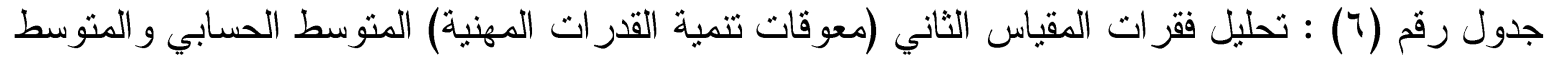

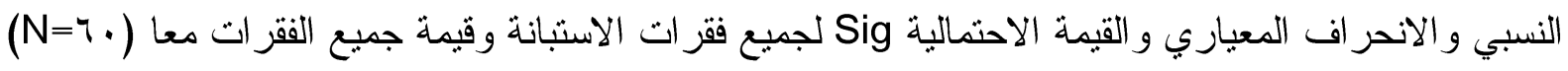


نوال بنت صويلح حمدان الجهني

\begin{tabular}{|c|c|c|c|c|c|c|c|}
\hline 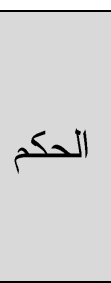 & التزتيب & الاحتمالية & الانحر المعيار & النسبي & المسابي & الفقر ات & r \\
\hline كبيرة & r & $\ldots$ &. $.9 \varepsilon$ & $\wedge r . . . \%$ & $\leqslant .10$ & التقار برامج التنمية المهنية للخبر ات & 1 \\
\hline كبيرة & 0 & $\ldots$ & 1.10 & Vo. $7 v \%$ & r.vA & عدم القدرة على وضع خطة زمنية لتطوير & $r$ \\
\hline كبيرة & 7 & $\ldots$ & $1 \ldots$ & $\vee r . T \vee \%$ & $r .4 \lambda$ & ندرة إقامة بر امج للتنمية المهنية داخل & $r$ \\
\hline كبيزة & 1 & $\ldots$ &..$\vee 9$ & $91.7 \vee \%$ & $\varepsilon .01$ & كثرة الأعباء الأسرية للمعلمة. & $\varepsilon$ \\
\hline كبيرة & $\varepsilon$ & $\cdots$ & $1.1 \varepsilon$ & VV.rT\% & r.AV & هدر وقت التنديب في مناقشات جانبية لا & 0 \\
\hline كبيرة & $r$ & $\cdots$ & $1 . .7$ & $\vee q \ldots \%$ & $r .90$ & ندرة مصادر التعلم الذاتية للمعلمة في & 7 \\
\hline كبيزة & & $\ldots$ & $\therefore v$. & $\wedge . . \cdot \vee \%$ & $\varepsilon \ldots$ & الدرجة الكلية للمقياس الثاني & \\
\hline
\end{tabular}

1. المقياس الثاني دال إحصائيا حسب المحك المعتمد، وبلغ المتوسط الحسابي للمقياس ككل (....؛)، وبــوزن

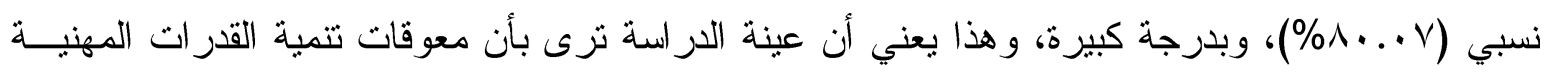

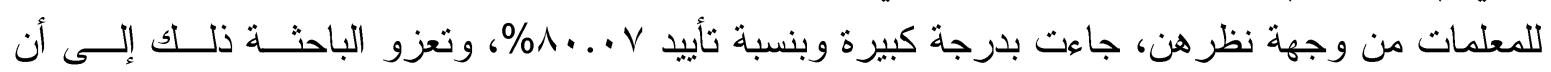
التنمية المهنية للمعلمات تسير وفقًا لإجر اءات وخطط نقلتيدية.

r. جاءت في المرتبة الأولى الفقرة رقم (乏) و التي تتص على "كثرة الأعباء الأسرية للمعلمة"، بمتوسط حسابي

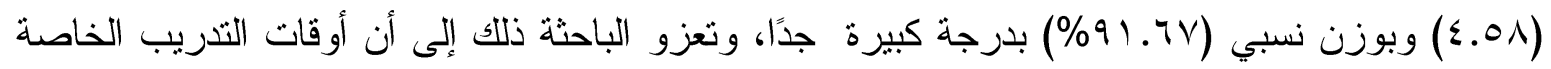

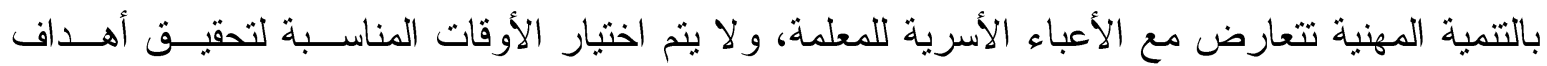

التنمية المهنية.

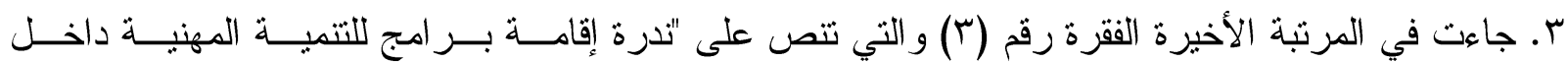

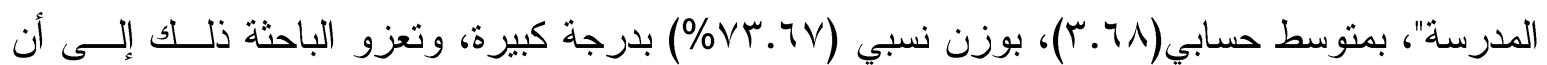
بر امج التنمية المهنية تتم خارج المدرسة وفي مر اكز وقاعات التنريب الخارجية. الإجابة على السؤال الثالث: "ما التصور المقترح لبرنامج يعتمد على الذكاء الاصطناعي لتحديـــــالاحتياجــات

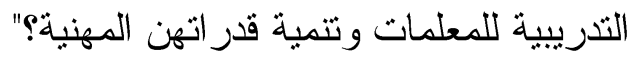

وللإجابة على هذا السؤال قامت الباحثة بدر اسة معوقات تحديد الاحتياجات التنريبية للمعلمات، ومعوقات تتمية

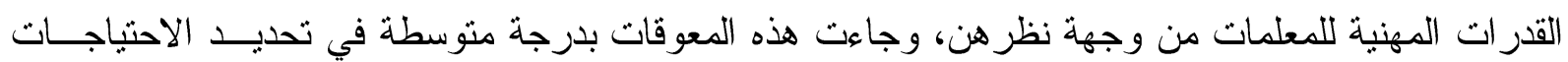




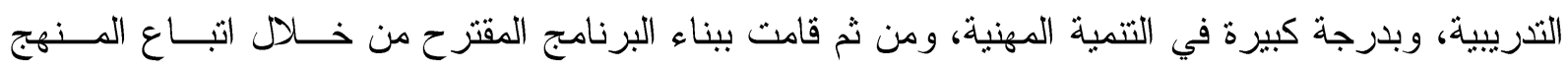

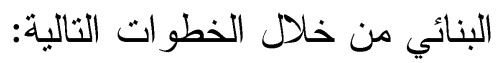

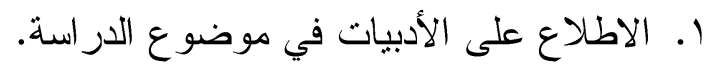

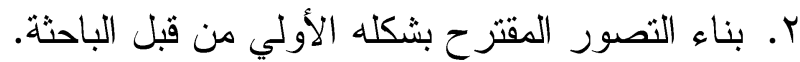

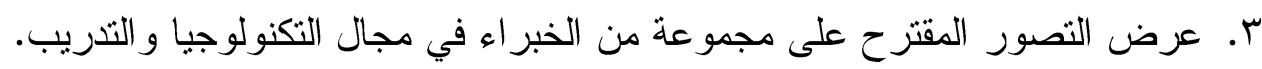

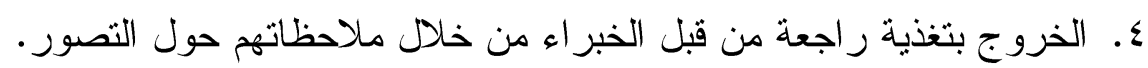

0. - 20 بناء التصور بصورته النهائية.

$$
\text { وكان التصور المقترح حسب النالي: }
$$

\section{التصور المقترح لبرنامج بعتمد على الذكاء الاصطناعي لتصديد الاحتباجات التتريية للمعلمات وتنمبة}

\section{قتراتهن المهنية:}

مقدمة:

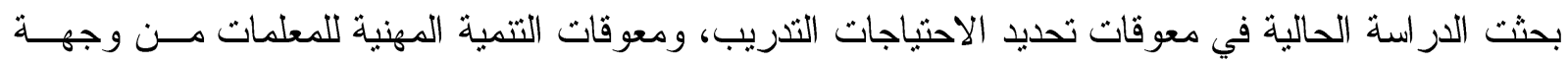

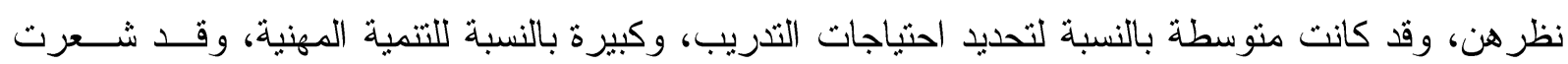

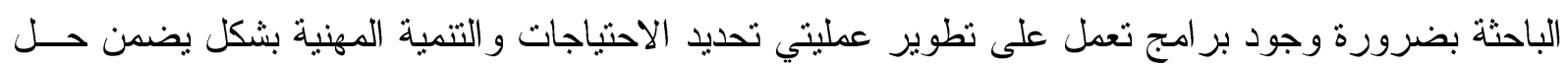

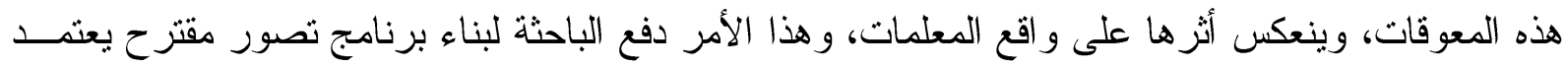

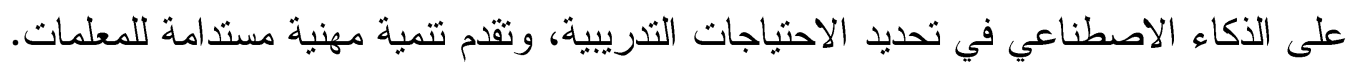

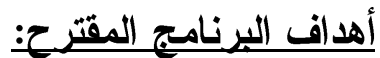

• تحديد الاحتياجات التدريبة لكل مجال من مجالات عمل المعلمات.

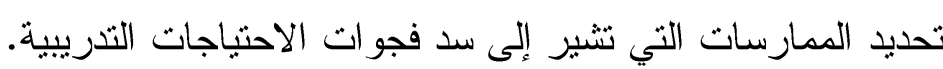

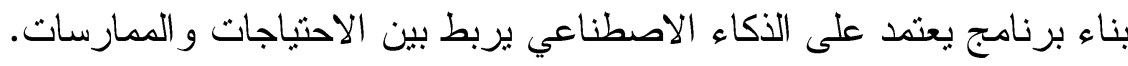

تطبيق البرنامج المعتمد على الذكاء الاصطناعي من قبل المعلمات و المشرفين.

منطلقات التصور المقترح:

أ) - (أ) منطلقات محلية:

المساهمة في تحقيق روئية المملكة .ب •.r.

المساهمة في حل مشكلات التدريب و التنمية المهنية.

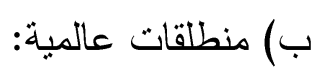

التوجه العالمي لتطبيق الذكاء الاصطناعي في التعليه.

الاهتمام العالمي بالمو ارد و القوى البشرية وتطوير ها لاصناعل بشل مستمر .

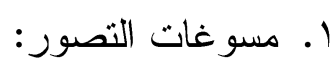

وجود معوقات في تحديد الاحتياجات التنريية للمعلمات. 


\section{Y. خطة التصور المقترح والإجراءات:}

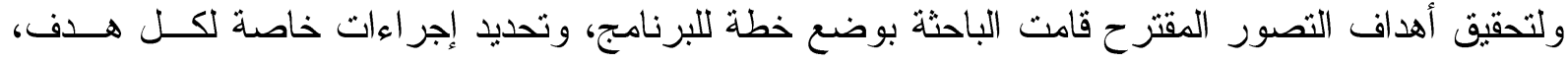
و الفئة المنفذة، ومؤشرات الأداء، وتركت الباحثة لجهة التتفيذ تحديد الوقت اللازم لتنفيذ هذه الخطة:

الهدف الأول: تحديد الاحتياجات التنريبة لكل مجال من مجالات عمل المعلمات.

\begin{tabular}{|c|c|c|}
\hline مؤشر ات الأداء & جهة التنفيذ & الإجر اءات \\
\hline وجود قائمة بأسماء الفرق & مشرفة & تشكيل فريق لتحديد الاحتياجات التذريبة للمعلمات \\
\hline قائمة بمجالات عمل المعلمات & الفريق & تحديد مجالات عمل المعلم (الإدارة الصفية، طر ائق التنريس، .....) \\
\hline قائمة بالأهداف لكل مجال & الفريق & تحديد الأهداف الو اجب تحقققها من قبل المعلم في كل مجال \\
\hline قائمة بالاحتباجات & الفريق & تحديد الاحتياجات التدريبة لكل هدف. \\
\hline قائمة بالمؤشر ات & 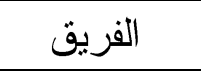 & تحديد مؤشر ات الأداء التي تثشير لسد فجو ات الاحتياجات التشريبة. \\
\hline تقديم تغذية راجعة للفريق حول العمل المقدم & مشرفة & مر اجعة وتقييم الاحتباجات التي تم تحديدها، ومدى ارتباطها بالأهداف المرجو \\
\hline تقديم تصور شامل وواضح & 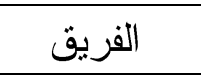 & الاعتماد بشكل نهائي للمجالات و الأهداف و الاحتياجات و المؤشر ات \\
\hline
\end{tabular}

الهدف الثاني: تحديد الممارسات التي نتشير إلى سد فجوات الاحتياجات التنريبية.

\begin{tabular}{|c|c|c|}
\hline مؤشر ات الأداء & جهة التتفيذ & الإجر اءات \\
\hline سلم تقدير & 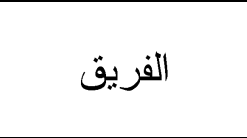 & تحديد سلم تقدير لكل مؤشر يشير إلى سد الفجوات التدريبة التي تم \\
\hline قائمة بالممارسات & 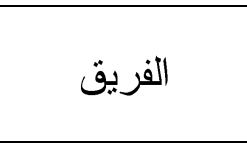 & تحديد الممارسات الو اجب القيام بها من قبل المعلمات لتحقيق كل \\
\hline صياغة بشكل و اقعي & 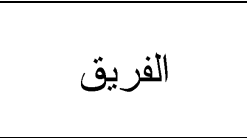 & صياغة الممارسات بشكل بطابق و اقع عمل المعلمات، وربطها \\
\hline تقديم تغذية راجعة للفريق & مشرفة التدريب & تقويم صياغة المؤشر ات ومدى ارتباطها بالو اقع. \\
\hline قائمة بسلم التقدير موزع على الممارسات. & 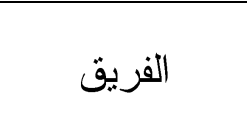 & ربط سلم التقبير لكل مؤشرة وتوزيعه على الممارسات. \\
\hline تقديم التصور النهائي للممارسات & مشرفة التذريب & الاعتماد النهائي لقائمة الممارسات المرتبطة بكل مؤشر من مؤشر ات \\
\hline
\end{tabular}

الهدف الثالث: بناء برنامج بعتمد على الذكاء الاصطناعي بربط بين الاحتياجات و الممارسات.

\begin{tabular}{|c|c|c|}
\hline 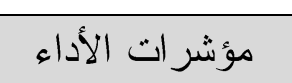 & جهة التنفيذ & الإجر اءات \\
\hline تحليل نظام متكامل & الفريق & تحليل نظام البرنامج الذي سبحتمد على الذكاء الاصطناعي في تحديد \\
\hline
\end{tabular}


نوال بنت صويلح حمدان الجهني

العدد التاسع عشر يناير 9 ب مب

\begin{tabular}{|c|c|c|}
\hline مؤشر ات الأداء & جهة التتفيذ & الإجر اءات \\
\hline & & الاحتياجات و التتمية المهنية. \\
\hline قائمة بالأقسام و الثاشات & الفريق & تحديد أقسام البرنامج، و الثاشات الرئيسية. \\
\hline قاعدة بيانات للممارسات & 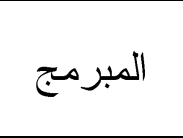 & تزويد البرنامج بالممارسات التي سيقوم بها المعلم لسد الثغرات \\
\hline تجريب الربط & 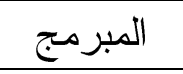 & ربط الممارسات بالاحتياجات التنريبية. \\
\hline تجريب إصدار الحكم & 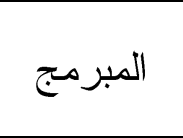 & تزويد البرنامج بآلية إصدار الحكم على مدى الاحتياجات التثريبة \\
\hline 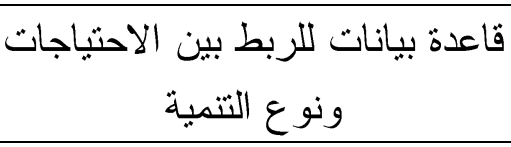 & 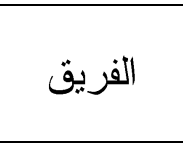 & تزويد البرنامج بأنواع التنمية المهنية المر اد تزويد المعلم بها، \\
\hline قاعدة بيانات بالآليات و المر احل & 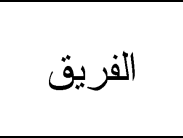 & تزويد البرنامج بآليات ومر احل التنمية المهنية المر اد نطبيقها مع \\
\hline وجود آليات و اضحة للتقويم & 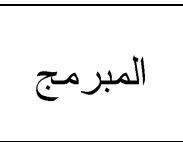 & تزويد البرنامج بآلية تقويم تقدام المعلم في برنامج التنمية المهنية وسد التديبة \\
\hline
\end{tabular}

الهدف الر ابع: تطبيق البرنامج المعتمد على الذكاء الاصطناعي من قبل المعلمات و المشرفين.

\begin{tabular}{|c|c|c|}
\hline مؤشر ات الأداء & جهة التتفيذ & 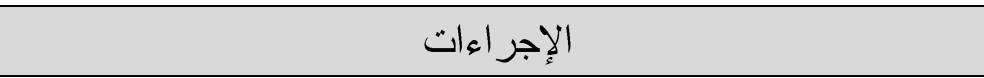 \\
\hline تطبيق البرنامج وملاحظة إصدار & الفريق ومشرفة التدريب & التجريب الأولي للبرنامج من قبل الفزيق. \\
\hline تتفيذ التعديلات المطلوبة & 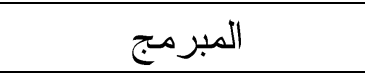 & التعديل بعد التجريب الاولي من قبل الفريق. \\
\hline ملاحظة الأحكام الصادرة & مشرفة التدريب & تطبيق البرنامج على عبنة من المعلمات بشكل قصدي. \\
\hline إجر اء التعديلات النهائية & 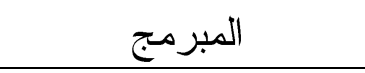 & التعديل على البرنامج بعد التطبيق على عينة قصدية من المعلمات. \\
\hline وجود قائمة بالممارسات في & 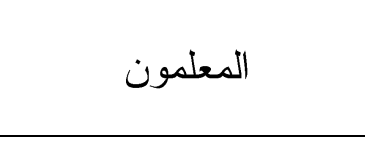 & التطبيق الفعلي للبرنامج من قبل المعلمات، من خلال كتابة تقارير \\
\hline وجل قادة قائمة ممارسة مكتوبة من وارس و المشرفين & المشرفون التزبويون، & التطبيق الفعلي من قبل قادة المدارس و المشرفين من خلال كتابة العملية فئل المدرسة. \\
\hline وصول قائمة بالاحتباجات & 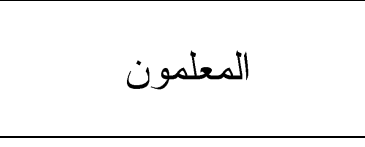 & إصدار الحكم من قبل البرنامج بالاحتياجات التنريبة لكل معلم. \\
\hline وصول قائمة بير امج التنمية & 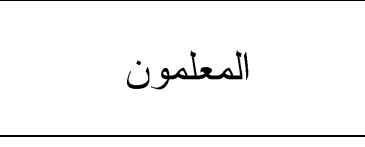 & اقتر اح برنامج التتمية المهنية المرغوب لكل معلم من قبل البرنامج، والمبات التبريبة. \\
\hline وجود أنشطة ينفذها المعلم خاصة & 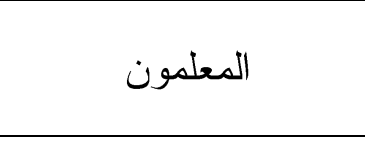 & تفاعل المعلم مع بر امج التتمية المهنية المقترح. \\
\hline إصدار حكم من البرنامج & المعلمون - الم & تقويم أداء المعلم في برنامج التنمبة الدهنية. \\
\hline وجود إصدار ات محدثة من & 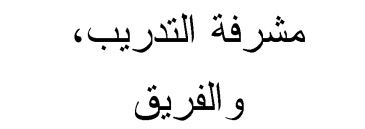 & تطوير البرنامج بشكل مستمر ليتتاسب مع التغير ات الجديدة في \\
\hline
\end{tabular}


r. المعوقات التي قد تواجه التصور المتقرح.

عدم قناعة المسئولين بأهمية بر امج الذكاء الاصطناعي.

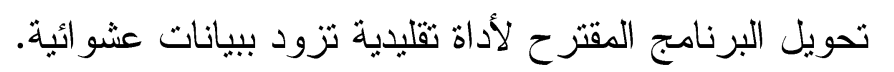

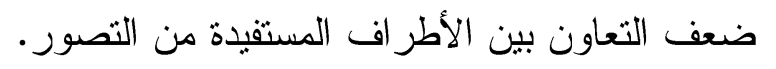

\section{๑- ملغص النتائج:}

ا. قدمت الدراسة تصورًا مقترحًا لبرنامج يعتمد على الذكاء الاصطناعي لتحديد الاحتباجـات الندريبيــة للمعلمات وتتمية قدر اتهن المهنية.

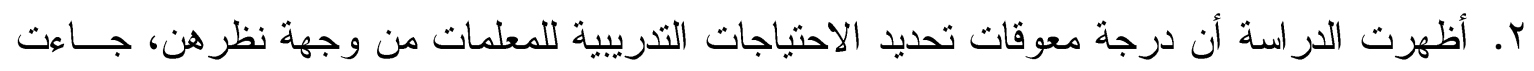

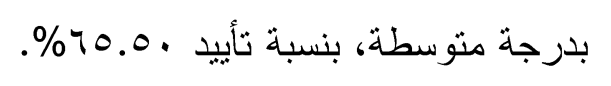

r. أظهرت الدر اسة أن معوقات تتمية القدر ات المهنية للمعلمات من وجهة نظرهن، جاءت بدرجة كبيــرة

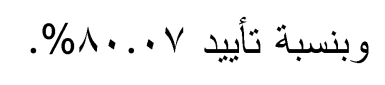

ـ. بينت الدراسة أن أكثر المعوقات في تحديد الاحتباجات التدريبية للمعلمات كان في "عدم تحديد فجوات

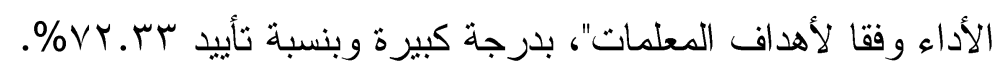

ه. بينت الدراسة أن أكثر معوقات التتمية المهنية للمعلمات كان "كثرة الأعباء الأسرية للمعلمة"، بدرجـة

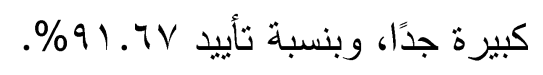

\section{؛. ـ التوصيات:}

1. تبني التصور المقترح من قبل وزارة التعليم في المملكة العربية السعودية.

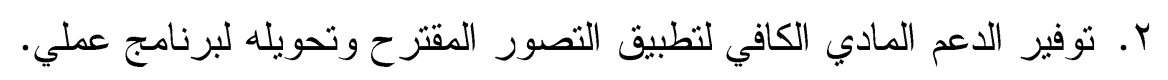

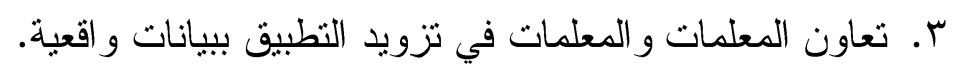

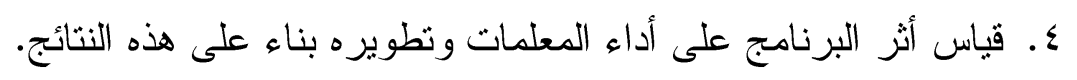




\section{مراجع الدراسة}

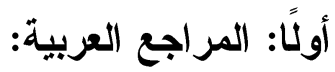

1. إبر اهيم، عبدالرحمن و المسند، شيخة (ع . . ب). الاتجاهات العالمية في إعداد وتدريب المعلمات

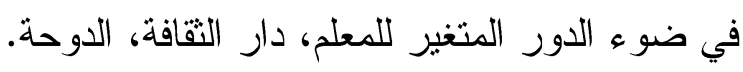

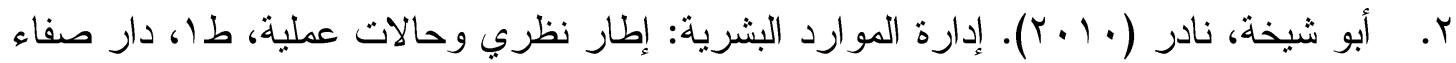

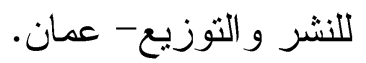

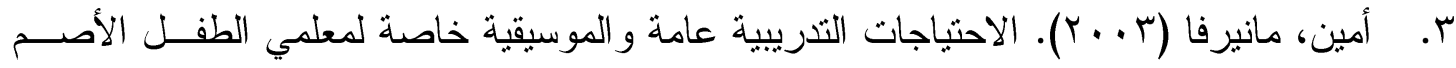

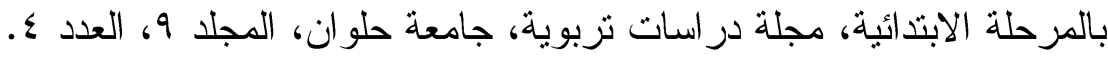

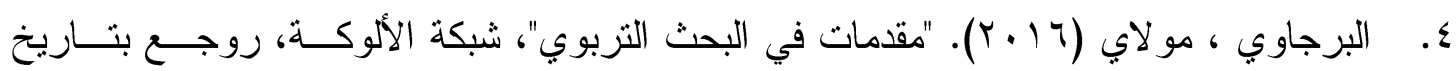

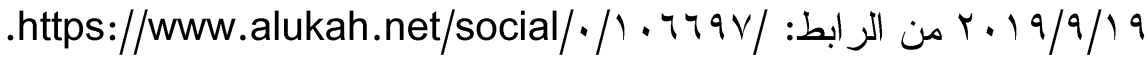

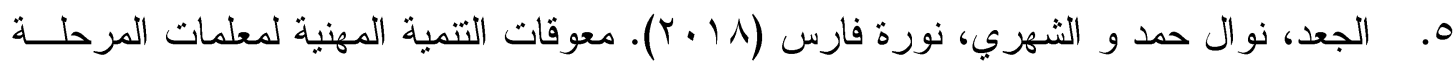

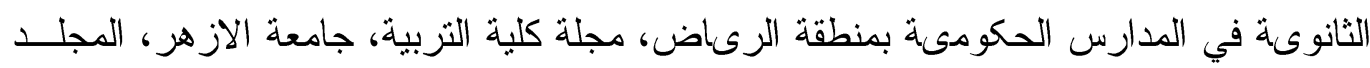
الج

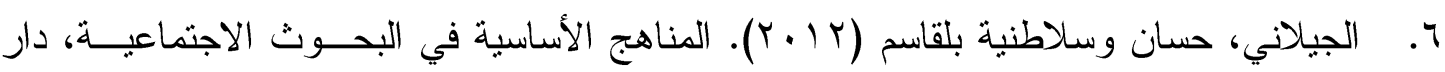

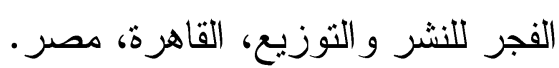

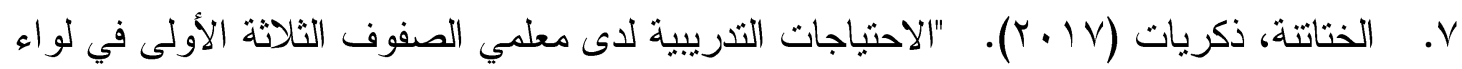

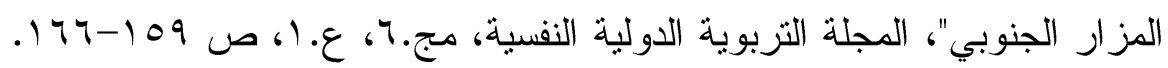

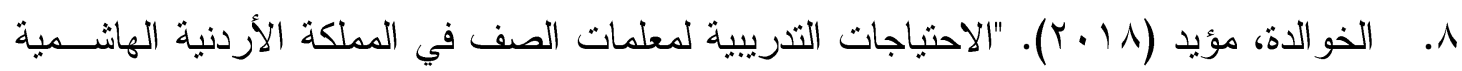

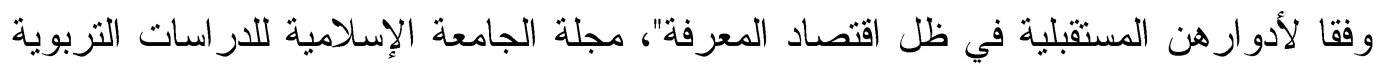

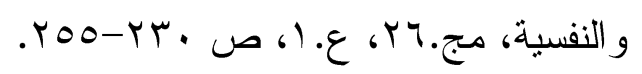

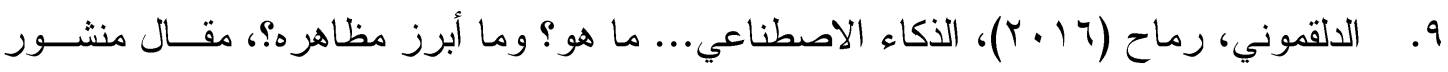

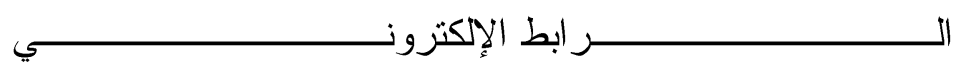

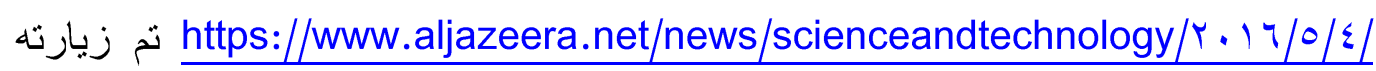

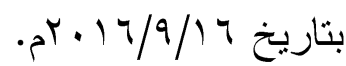

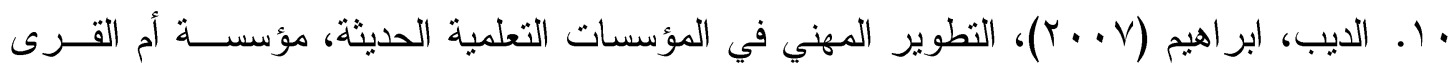

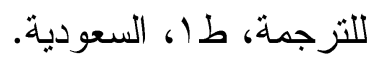

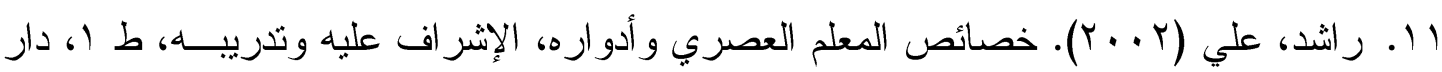

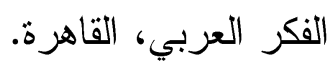

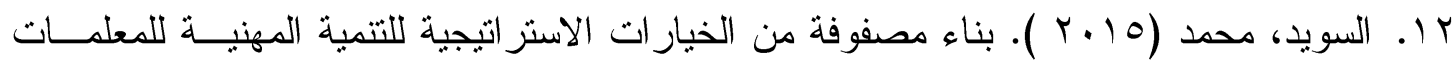

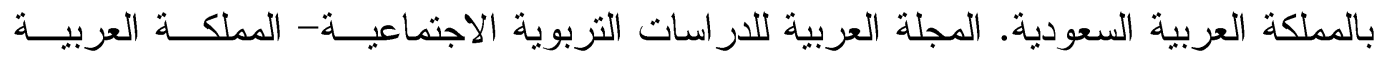

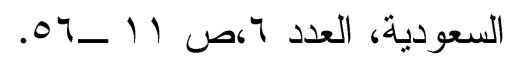

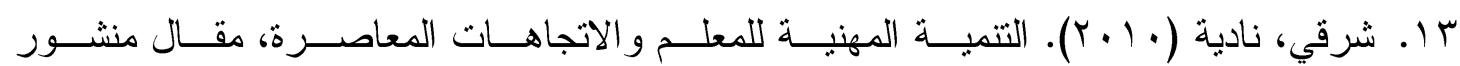
على الز ابط: http://www.edutrapedia.illaf.net/arabic/show_article.thtml?id=V/.

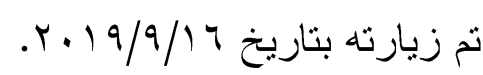
ـ ا. الثمري، ثاني(9 (ب) ب). "دور النعلم الرقمي في التنمية المهنية للمعلمات"، المجلة العربية للعلوم 


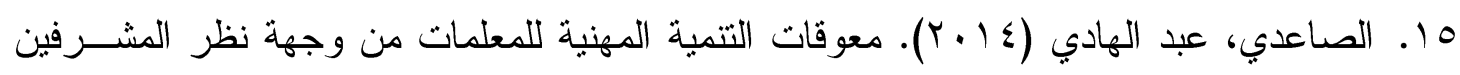

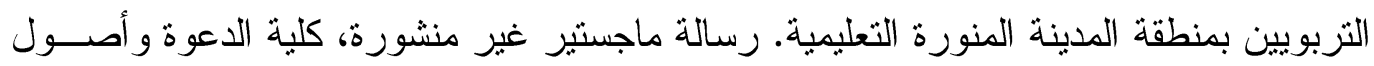
الدين، الجامعة الإسلامية، المملكة العربية السعودية، المدينة المناية المنورة.

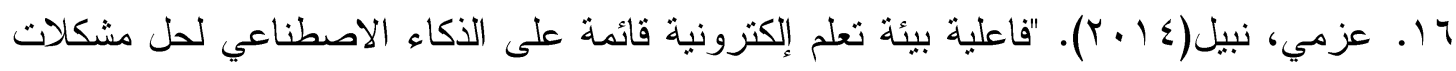

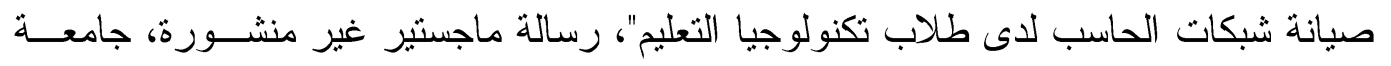
حلو ان، حلو ان، مصر . مان.

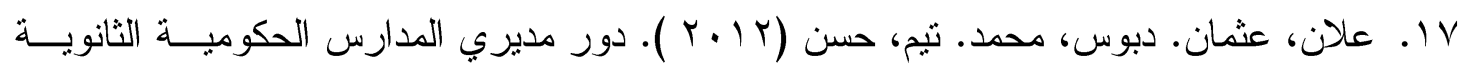

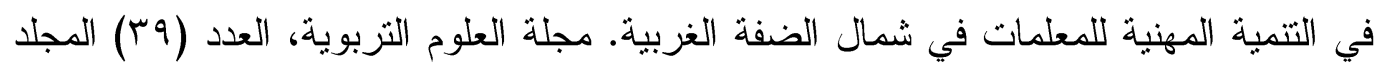
(1)

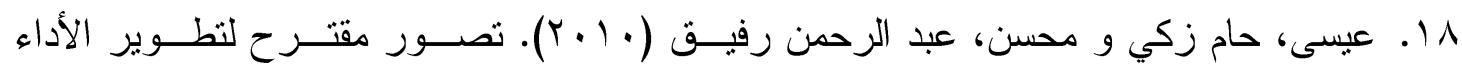

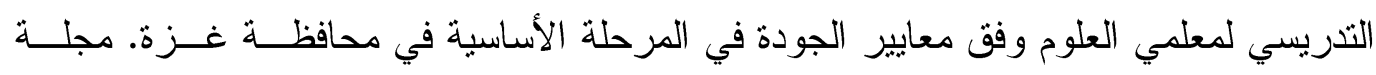

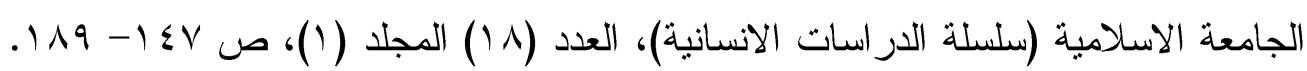

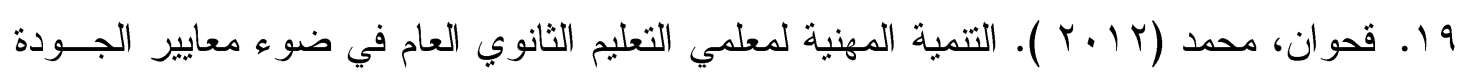

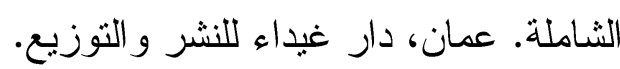

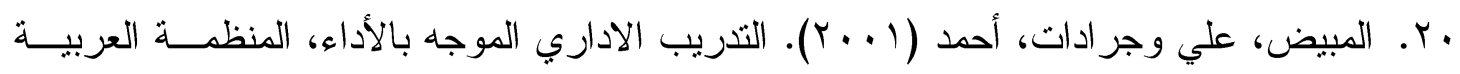

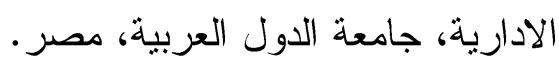

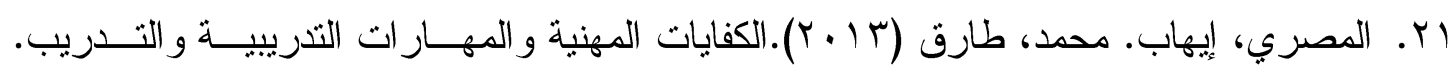

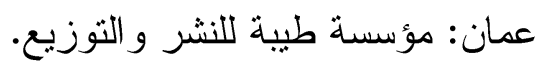

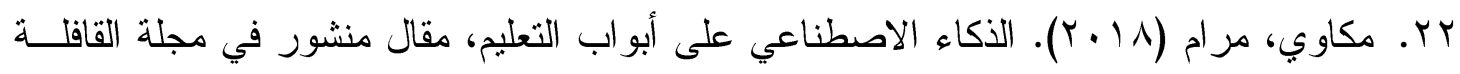

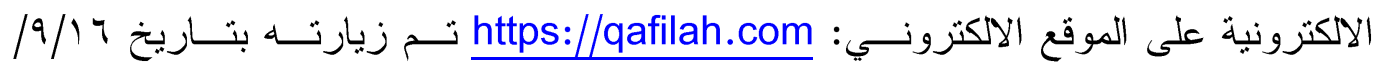
. 19

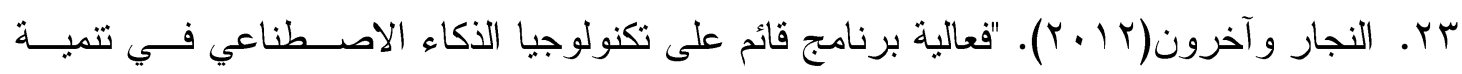

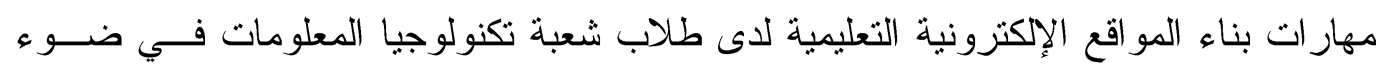

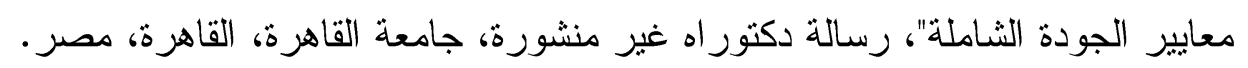

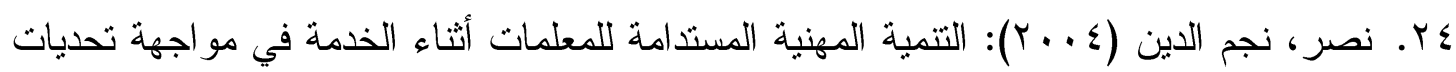

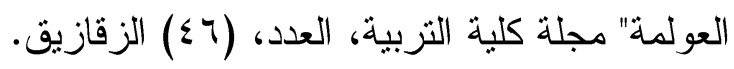

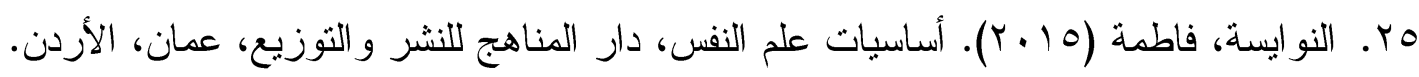

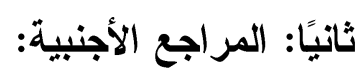

1. Krishna, Reddy $(Y \cdot \mid \wedge)$. Advantages and Disadvantages of Artificial Intelligence, web site https://content.wisestep.com/advantagesdisadvantages-artificial-intelligence/, 1 1 /9/ + 19 .

ఛ. Negnevitsky, micheal ( $\uparrow_{\ldots}$. $)$ Intelligence Systems, first edition , Hobart, Tasmania, Australia 


\section{ملحق الارساسة (الاستبانة)}

تم تصميم استطلاع رأي عبر الإنترنت لنشر الاستبانة بغرض جمع المعلومات من عينة الدارسة وكانت على الشكل النالي: تصور مقترح لبرنامج يعتد على الذكاء الاصطناعي لتحديد الاحتياجات التدريبية للمعلمات وتتميــة قــدر اتهن المهنية عزيزتي المعلمة المكرمة:

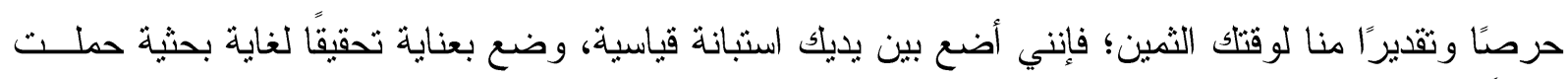

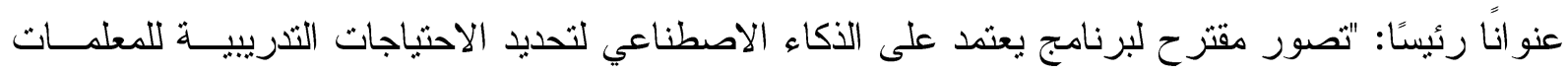

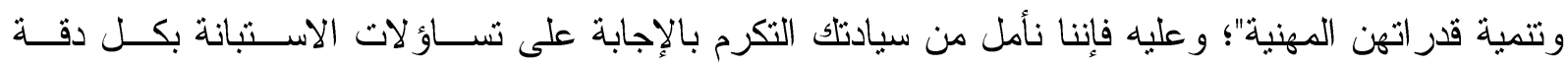

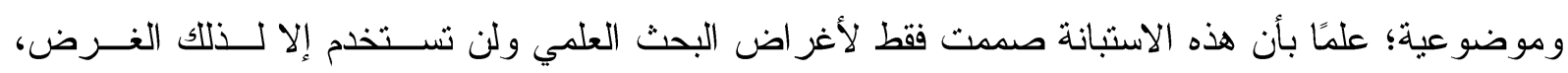
شاكرين للك حسن تعاونك معنا. إعداد الباحثة: نو ال الجهني القسم الأول: البيانات الثخصية: بكالوريوس प 1. المؤهل العلمي:

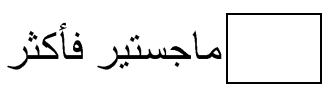
$\square$ $\square$ r. سنوات الخدمة :<smiles>C[As][As]C=[13C]C1CCC1</smiles> 
القسم الثانى: معوقات تحديد الاحتياجات التدريبية للمعلمات.

\begin{tabular}{|c|c|c|c|c|c|c|}
\hline \multicolumn{5}{|c|}{ درجة التو افز } & \multirow[b]{2}{*}{ الفقرة } & \multirow[b]{2}{*}{ 5 } \\
\hline قدًا & قليلة & سطة & كبيرة & كبار & & \\
\hline & & & & & قلكة ربط تقييم أداء المعلم بالاحتباجات التدريبية. & 1 \\
\hline & & & & & عدم تعاون المعلمات في تحديد احتياجاتهم التدرييية. & r \\
\hline & & & & & للمعلم. ضعف في موضوعية قائد المدرسة في تحديد الاحتباجات التنرييية & r \\
\hline & & & & & عدم تحديد فجو ات الأداء وفقا لأهداف المعلمات. & $\varepsilon$ \\
\hline & & & & & عدم قناعة المعلمات بأهية تحديد الاحتباجات التدريبية. & ० \\
\hline & & & & & شعور المعلم بكفايته من الاحتباجات التدريبة. & 7 \\
\hline
\end{tabular}

القسم الثالث: ما معوقات تتمية القدر ات المهنية للمعلمات.

\begin{tabular}{|c|c|c|c|c|c|c|}
\hline \multicolumn{5}{|c|}{ درجة التو افز } & \multirow[b]{2}{*}{ 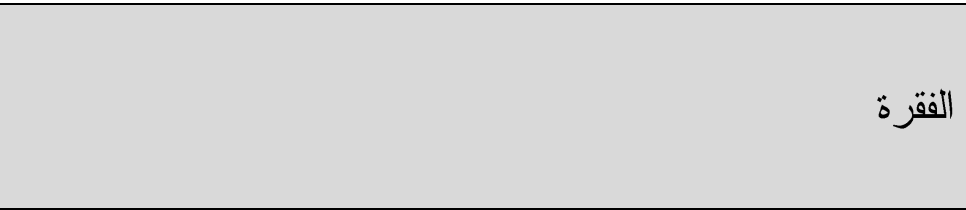 } & \multirow[b]{2}{*}{ s } \\
\hline جدًا & قليلة & سطة & كبيرة & كبيرة & & \\
\hline & & & & & |فتقار برامج التتمبة المهنية للخبرات العالمبة المعاصرة. & 1 \\
\hline & & & & & | عدم القدرة على وضع خطة زمنية لتطوير الذات. & r \\
\hline & & & & & | ندرة إقامة برامج للتنمية المهنية داخل المدرسة. & r \\
\hline & & & & & كثرة الأعباء الأسرية للمعلمة. & $\varepsilon$ \\
\hline & & & & & 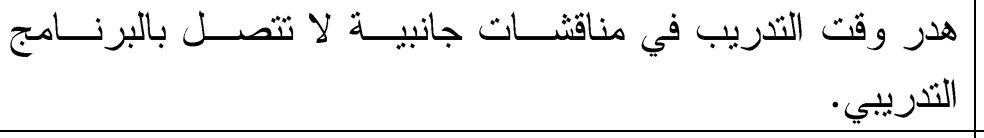 & 。 \\
\hline & & & & & |ندرة مصادر التعلم الذاتية للمعلمة في المدرسة. & 1 \\
\hline
\end{tabular}

